\title{
Deficient autophagy drives aging in Hydra
}

\author{
Szymon TOMCZYK ${ }^{1}$, Quentin SCHENKELAARS ${ }^{1}$, Nenad SUKNOVIC ${ }^{1}$, Yvan WENGER ${ }^{1}$, Kazadi EKUNDAYO ${ }^{1}$, \\ Wanda BUZGARIU ${ }^{1}$, Christoph BAUER ${ }^{1}$, Kathleen FISCHER $^{2}$, Steven AUSTAD ${ }^{2}$ and Brigitte GALLIOT ${ }^{1 *}$
}

\footnotetext{
${ }^{1}$ Department of Genetics and Evolution, Institute of Genetics and Genomics in Geneva (iGE3), University of Geneva, Geneva, Switzerland; ${ }^{2}$ Department of Biology, University of Alabama at Birmingham, USA
}

*Corresponding author: brigitte.galliot@unige.ch

\begin{abstract}
Hydra exhibits a negligible senescence as its epithelial and interstitial stem cell populations continuously divide. Here we identified two $H$. oligactis strains that respond differently to interstitial stem cell loss. Cold-resistant $\left(H_{0}\right.$ C $\left.C R\right)$ animals adapt and remain healthy while coldsensitive (Ho_CS) ones die within three months, after their epithelial stem cells lose their selfrenewal potential. In $\mathrm{Ho}_{-} \mathrm{CS}$ but not in $\mathrm{Ho}_{-} \mathrm{CR}$ animals, the autophagy flux is deficient, characterized by a low induction upon starvation, proteasome inhibition or Rapamycin treatment, and a constitutively repressed Ulk activity. In the non-aging Hydra vulgaris, WIPI2 silencing suffices to induce aging. Rapamycin can delay aging by sustaining epithelial self-renewal and regeneration, although without enhancing the autophagy flux. Instead Rapamycin promotes engulfment in epithelial cells where p62/SQSTM1-positive phagocytic vacuoles accumulate. This study uncovers the importance of autophagy in the longevity of early-branched eumetazoans by maintaining stem cell renewal, and a novel anti-aging effect of Rapamycin via phagocytosis.
\end{abstract}

\section{Key words:}

Hydra model system; aging mechanisms; regeneration; epithelial stem cells; autophagy; proteostasis; Rapamycin; p62/SQSTM1; ULK1; WIPI2

Studies using short-lived invertebrate organisms as the fruit fly or the nematode dramatically improved our understanding of aging (Longo and Finch 2003). However these model systems have some drawbacks such as developmental pausing, which might be activated when lifespan is experimentally prolonged, thus implying a mechanism different from mammalian aging (Austad 2009). Also except for the Drosophila gut, somatic tissues in adult flies and nematodes do not self-renew, while self-renewal is an essential component of homeostasis in humans. Finally, a significant proportion of human orthologous genes were lost in fly and nematodes as evidenced by their presence in cnidarians, a bilaterian sister group (Figure 1A) (Wenger and Galliot 2013; Schenkelaars et al. 2017). Therefore, additional invertebrate models could be profitably developed to help discover novel genes, pathways and mechanisms relevant for human aging.

Hydra is a small carnivorous freshwater cnidarian polyp (Figure 1B), characterized by a dynamic homeostasis and the ability to regenerate any missing part after amputation (Galliot 2012). It expresses a large number of vertebrate orthologs along its radially organized bilayered body plan. In culture conditions mortality of Hydra vulgaris (Hv) remains negligible over the years (Brien 1953; Martinez 1998) and wellfed animals remain asexual, reproducing by budding without showing replicative senescence (Schaible et al. 2015). Hence, Hydra seems to escape aging, an unusual property likely attributed to its three distinct stem cell populations that constantly self-renew in the central body column. The epidermal and gastrodermal epithelial stem cells (eESC, gESC) are multifunctional unipotent stem cells, while the interstitial stem cells (ISC) are multipotent, providing both somatic and germ cells (Figure 1C). ISCs and interstitial progenitors (collectively named i-cells) cycle much faster than ESCs; as a result animals 
bioRxiv preprint doi: https://doi.org/10.1101/236638; this version posted December 23, 2017. The copyright holder for this preprint (which was not certified by peer review) is the author/funder, who has granted bioRxiv a license to display the preprint in perpetuity. It is made available under aCC-BY-NC-ND 4.0 International license.

Tomczyk et al.

Deficient autophagy and aging in Hydra

transiently exposed to anti-proliferative drugs rapidly lose their i-cells and progressively become epithelial (Marcum and Campbell 1978; Sugiyama and Fujisawa 1978; Buzgariu et al. 2014). If force-fed, such epithelial Hydra remain viable, able to bud and regenerate (Marcum and Campbell 1978; Sugiyama and Fujisawa 1978), likely due to the rapid adaptation of their ESCs that modify their genetic program (Wenger et al. 2016).

However aging was reported in a species named H. oligactis (Ho) (Figure 1A) (Brien 1953; Littlefield et al. 1991). A rapid temperature drop to $10^{\circ} \mathrm{C}$ suffices to induce gametogenesis in Ho animals that rapidly stop budding, produce gametes and degenerate. This process, characterized by somatic i-cell loss, cytoskeleton disorganization, decline in body movements and feeding behavior, was identified as aging (Yoshida et al. 2006). In male and female Ho strains, sexual animals die within four months, showing Gompertzian mortality dynamics (Finch 1990). As $H o$ animals maintained at $18^{\circ} \mathrm{C}$ exhibit no signs of aging, we used cold transfer to induce aging experimentally in two Ho strains, one cold-sensitive (Ho_CS) that undergoes aging, and another, cold-resistant $\left(H_{0} \_C R\right)$ that survives gametogenesis. We show that these two strains exhibit striking differences in autophagy efficiency and in stem cell self-renewal. An inducible autophagy flux appears essential to prevent aging in Hydra, as WIPI2 silencing suffices to shorten Hv survival. In Ho_CS a chronic Rapamycin treatment delays aging by stimulating epithelial phagocytosis and lipid droplet accumulation without rescuing autophagy.

\section{RESULTS}

\section{Ho_CR and Ho_CS respond differently to cold exposure}

To investigate aging in $\mathrm{Ho}$, we used two closely related male strains that exhibit similar budding regulation at $18^{\circ} \mathrm{C}$ (Figure_S1A) but respond differently to cold exposure. After cold transfer, $\sim 70 \%$ Ho_CR animals remain asexual and healthy while $\sim 30 \%$ differentiate testes that reach maturity within 25 days, then lose sexual traits and return to physiological fitness without stopping budding or exhibiting aging signs (Figure 1D,1E, Figure_S1). After 300 days at $10^{\circ} \mathrm{C}$, all $H o \_C R$ animals are healthy, some showing mild dysmorphic signs (e.g. duplicated basal region, non-detached buds, not shown). By contrast, after transfer to $10^{\circ} \mathrm{C}$, Ho_CS animals stop budding (Figure_S1B), $10 \%$ remain asexual, while 90\% differentiate testes and show irreversible dysmorphic signs such as tentacle shrinking, head loss, stenosis of the body column as reported previously (Yoshida et al. 2006). Their survival time negatively correlates to the testis number (Figure_S1D,E). Within one month the animals lose the ability to regenerate (Figure 1F, 1G), show behavioral defects (Movie-S1A, S1B), while aging becomes irreversible (Figure_S1H-O). Hence Ho_CS but not Ho_CR animals undergo aging in response to coldinduced gametogenesis.

\section{Different cellular impact of gametogenesis in aging and non-aging Hydra}

To monitor the impact of gametogenesis on somatic interstitial derivatives, we first analyzed DNA profiles by flow cytometry (Buzgariu et al. 2014) and found an increase in S-phase cells at day-17, when testes produce spermatogonia, and a large proportion of haploid cells at day-36 (Figure 1H,1I). Next we found the ratio of somatic i-cells over ESCs steadily decreasing in Ho_CS but only transiently altered in Ho_CR (Figure 1J), indicating that germ cell production leads to depletion of somatic i-cells in Ho_CS. Indeed, nematoblasts, gland cells, neurons disappear within few weeks after transfer to $10^{\circ} \mathrm{C}$ in $\mathrm{Ho}_{-} \mathrm{CS}$ (Figure 1K,1L) while persisting in $\mathrm{Ho}_{-} \mathrm{CR}$ even after 300 days at $10^{\circ} \mathrm{C}$ (not shown). Next we analyzed by RNAseq the regulation of 20 i-cell markers in aging and non-aging $H o$ animals (Figure_S2A) and found several i-cell genes (cnnos2, PaxA, vasa1, vasa2, ZNF845, cnox-2) already up-regulated at day-25/day32 in Ho_CR but not in Ho_CS (Figure_S2B), consistent with a faster repopulation of i-cells in Ho_CR than in Ho_CS. This result confirms the dramatic and irreversible impact of gametogenesis on somatic interstitial lineages in $\mathrm{Ho}_{-} \mathrm{CS}$ but not in $\mathrm{Ho}_{-} \mathrm{CR}$. As i-cell loss can be induced at $18^{\circ} \mathrm{C}$ by drugs or heatshock, we compared the profiles of i-cell markers in aging $\mathrm{Ho}$ animals and in drug-treated or heatshocked Hv animals (Wenger et al. 2016). We noted for 10/20 a more drastic reduction after drugs or heat-shock, indicating that gametogenesis leads to a more partial i-cell depletion (Figure_S2C). 
bioRxiv preprint doi: https://doi.org/10.1101/236638; this version posted December 23, 2017. The copyright holder for this preprint (which was not certified by peer review) is the author/funder, who has granted bioRxiv a license to display the preprint in perpetuity. It is made available under aCC-BY-NC-ND 4.0 International license.

Tomczyk et al.

Deficient autophagy and aging in Hydra

A

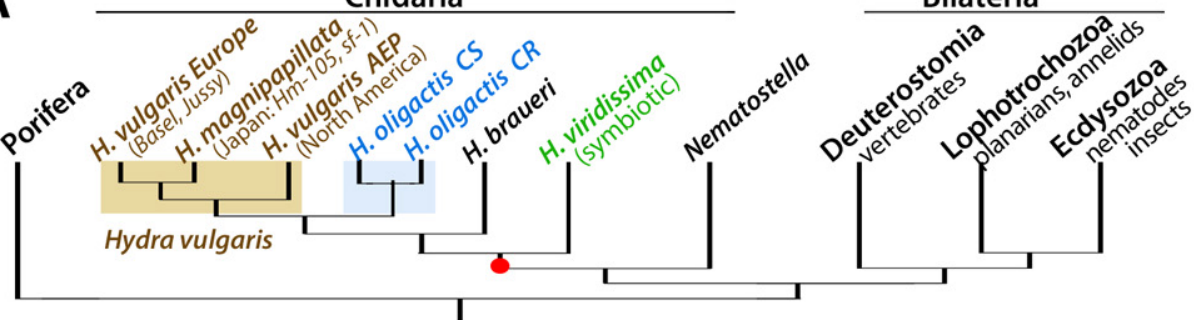

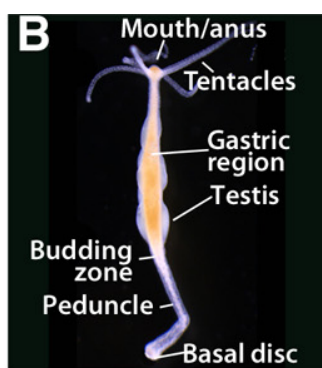

C

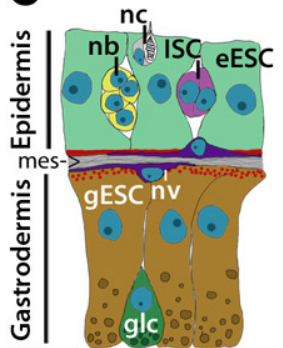

interstitial stem cells (ISC)

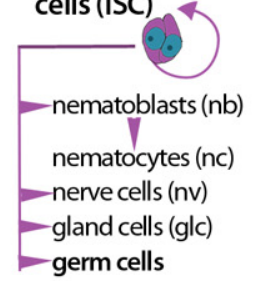

\section{E}
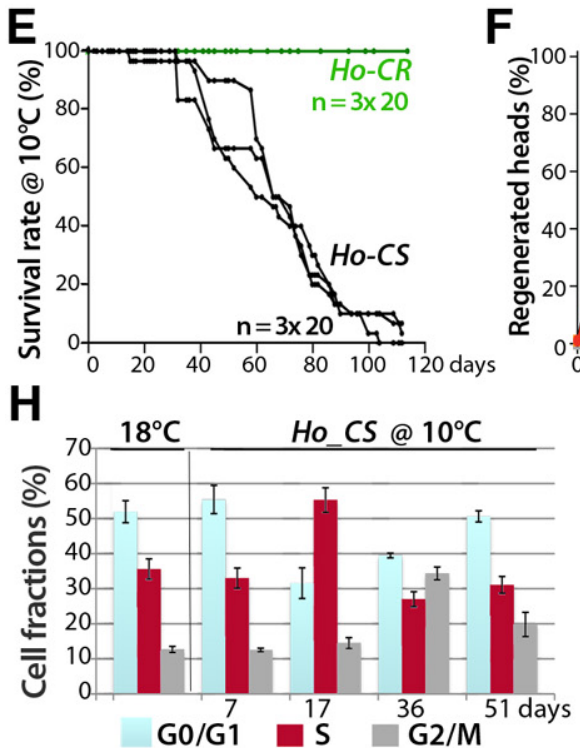

K

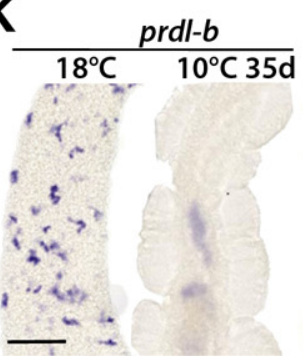

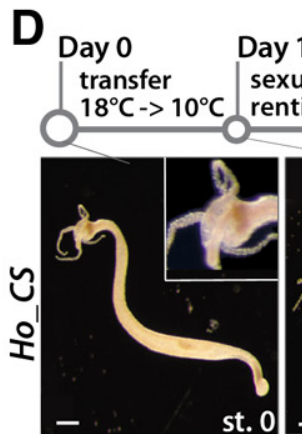

Day 14

Day 21 sexual
maturity

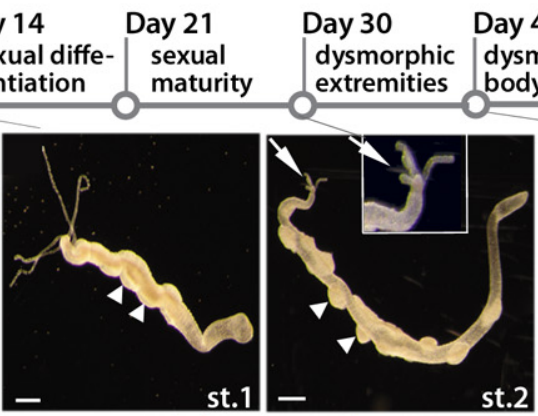

Day 40

Day 60

Day 90

\begin{tabular}{l|l} 
increase in & $\begin{array}{l}\text { fibrotic } \\
\text { mortality }\end{array}$ \\
tissues
\end{tabular}

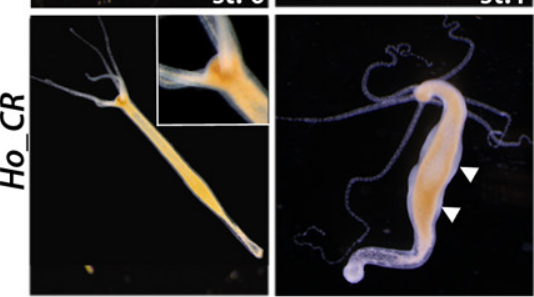

F
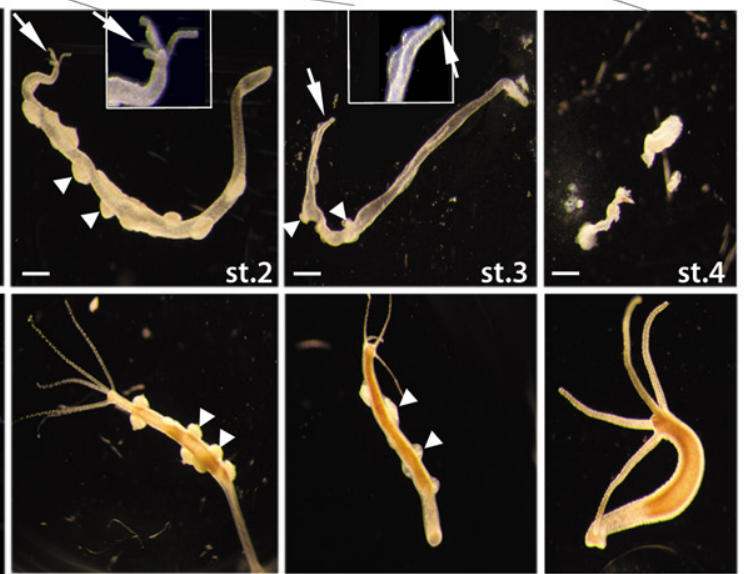

G
| 100

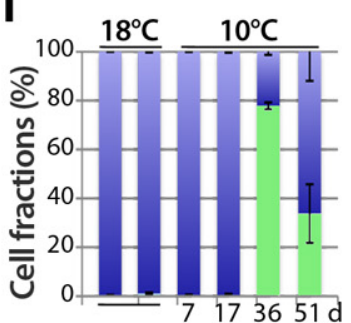

diploid haploid

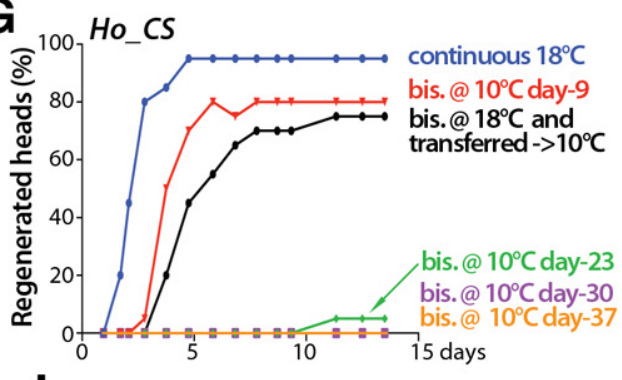

J

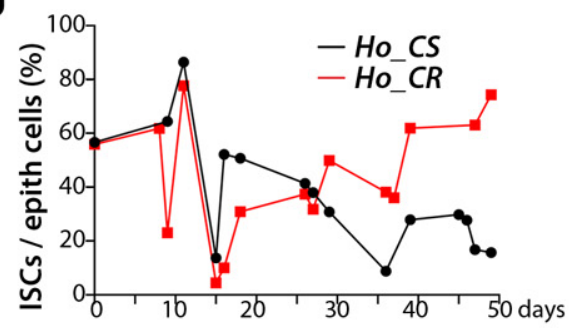

L Ho $C R 10^{\circ} \mathrm{C}$

Ho $\operatorname{CS~} 10^{\circ} \mathrm{C}$
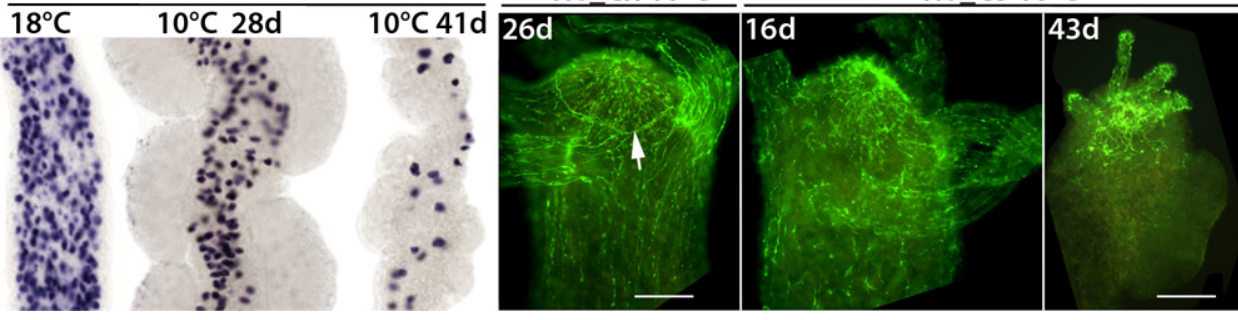

Figure 1: Inducible aging phenotype in cold sensitive Hydra oligactis (Ho_CS).

(A) Phylogenetic position of Hydra among metazoans. (B) Anatomy of a male H. oligactis animal. (C) Schematic view of Hydra gastric tissue; epidermal Epithelial Stem Cell (eESC), gastrodermal Epithelial Stem Cell (gESC), mesoglea (mes). (D) Morphological changes observed in Ho_CS (upper) and Ho_CR (lower) animals after transfer to $10^{\circ} \mathrm{C}$ (day 0 ); arrowheads: testes, arrows: degenerating head regions. Scale bar: $500 \mu \mathrm{m}$. (E) Survival rates among Ho_CR and Ho_CS cohorts. (F) Head regeneration measured in Ho_CR or Ho_CS animals selected for the presence or absence of testes and bisected at mid-gastric level after 24 days at $10^{\circ} \mathrm{C}$. (G) Head regeneration measured in Ho_CS animals bisected (bis.) either immediately before transfer to $10^{\circ} \mathrm{C}$ or $9,23,30$ or 37 days after transfer. $(\mathbf{H}, \mathbf{I})$ Modulations in DNA content profiles detected 
bioRxiv preprint doi: https://doi.org/10.1101/236638; this version posted December 23, 2017. The copyright holder for this preprint (which was not certified by peer review) is the author/funder, who has granted bioRxiv a license to display the preprint in perpetuity. It is made available under aCC-BY-NC-ND 4.0 International license.

Tomczyk et al.

Deficient autophagy and aging in Hydra

by flow cytometry in $\mathrm{Ho}_{\mathrm{C}} \mathrm{CS}$ animals maintained at $18^{\circ} \mathrm{C}$ or $10^{\circ} \mathrm{C}$. ( $\left.\mathbf{J}\right)$ Ratio of ISCs (single and pairs) over epithelial cells counted in macerated tissues (triplicates of $\sim 300$ cells). (K) Progressive elimination in cold-exposed Ho_CS of the prdl-b and Kazal1 expressing-cells that correspond to nematoblasts and gland cells respectively. Scale bar: $200 \mu \mathrm{m}$. (L) RFamidepositive neurons in apical regions of $H_{0} C R$ and Ho_CS animals; arrow: nerve ring. Scale bar: $100 \mu \mathrm{m}$.

\section{Aging can be induced independently of gametogenesis in Ho_CS}

To test whether i-cell depletion obtained in the absence of gametogenesis suffices to induce aging, we exposed animals maintained at $18^{\circ} \mathrm{C}$ to $\mathrm{HU}$ and left them unfed (Figure 2A). We noted in Ho_CS animals a typical aging phenotype as observed after cold-induced gametogenesis, although arising faster, including the epithelial myofiber disorganization (Figure 2B-2G). By contrast, we did not record any sign of aging in Ho_CR or $\mathrm{Hv}$ animals that rather exhibit a starvation phenotype, characterized by a reduced size but no dysmorphic features. Nevertheless $\mathrm{Ho}_{-} \mathrm{CS}$ as Ho_CR die within six weeks, while $\mathrm{Hv}$ animals

A

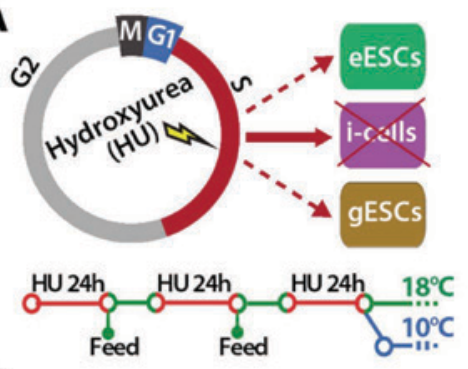

C

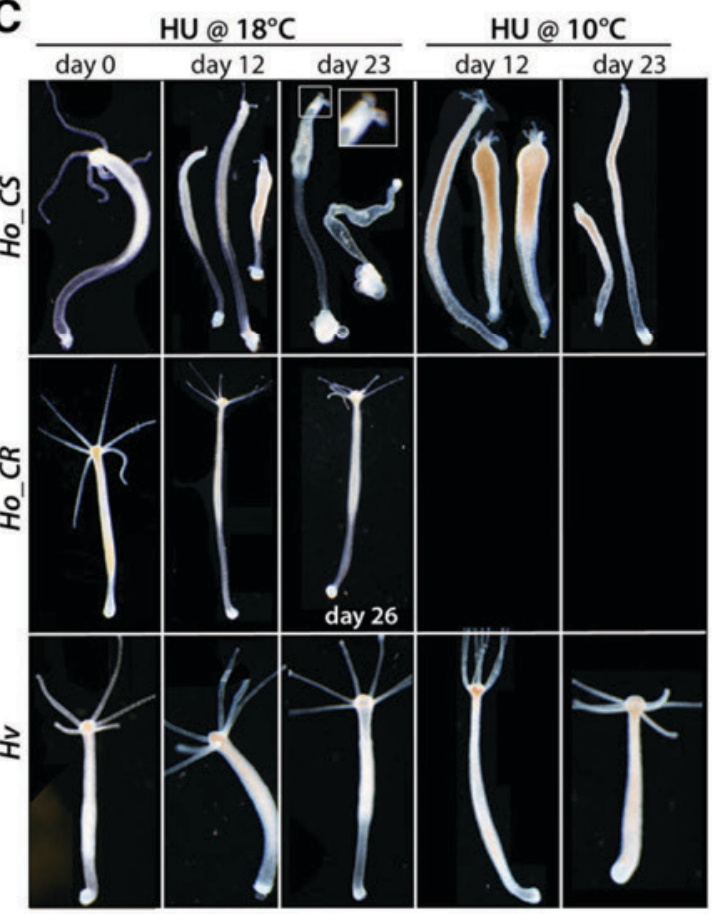

H

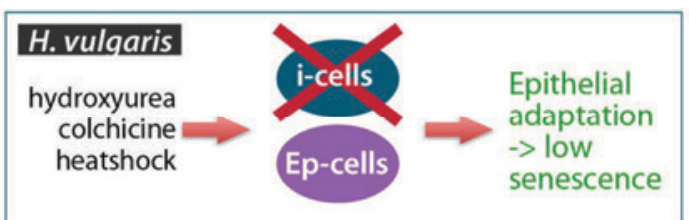

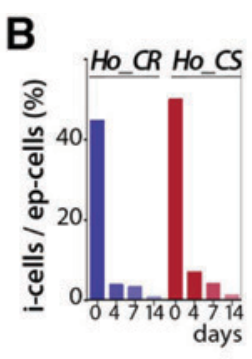
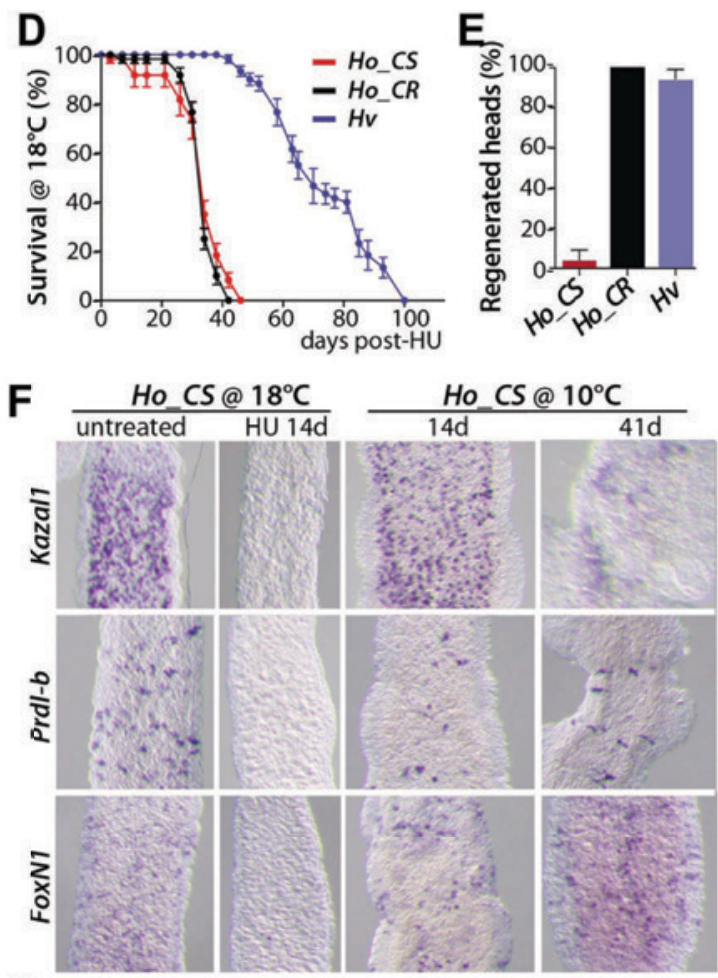

G
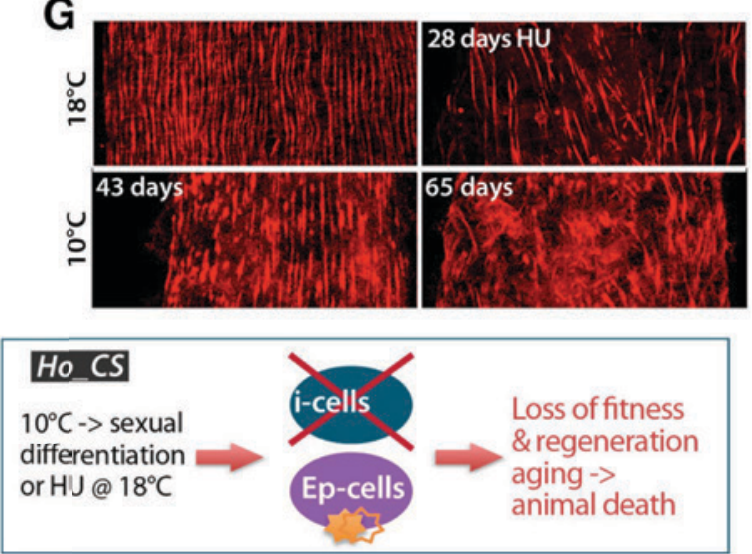

Figure 2: Pharmacological induction of aging in $\mathrm{Ho}_{-} \mathrm{CS}$ animals maintained at $18^{\circ} \mathrm{C}$

(A) Pulse treatments of hydroxyurea (HU) eliminate all ISCs but not ESCs as i-cells cycle 3-4x faster. (B) Interstitial cell ratios measured in HU-treated $\mathrm{Ho}_{-} \mathrm{CR}$ and $\mathrm{Ho}_{-} \mathrm{CS}$ animals maintained at $18^{\circ} \mathrm{C}$. (C) HU-induced morphological changes noted in Ho_CS, Ho_CR and $\mathrm{Hv}$ animals. Aging signs appear only in HU-treated Ho_CS animals. (D) Survival rate after HU treatment $(n=6 x 10)$. (E) Head regeneration rate of animals bisected 9 days after HU treatment $(n=3 x \quad 10)$. (F) Expression of Kazal-1, prdl-b and Fox-N1 (i-cell marker) in Ho_CS animals at indicated days after HU-treatment or transfer to $10^{\circ} \mathrm{C}$. (G) Phalloidin staining of eESCs in HU-treated or cold-exposed Ho_CS animals. (H) Scheme comparing the impact of i-cell loss in Hv animals where ESCs adapt (Wenger et al. 2016) and in Ho_CS, where a more limited loss is lethal, suggesting a lack of epithelial adaptation. 
bioRxiv preprint doi: https://doi.org/10.1101/236638; this version posted December $23,2017$. The copyright holder for this preprint (which was not certified by peer review) is the author/funder, who has granted bioRxiv a license to display the preprint in perpetuity. It is made available under aCC-BY-NC-ND 4.0 International license.

Tomczyk et al.

Deficient autophagy and aging in Hydra

resist twice longer to the $\mathrm{HU}$-induced i-cell depletion (Figure 2D). In conclusion, ISC loss in the absence of gametogenesis suffices to induce aging phenotypes in $\mathrm{Ho}_{-} \mathrm{CS}$ but not in $\mathrm{Ho}_{-} \mathrm{CR}$ animals. This result suggests that epithelial cells adapt to i-cell loss in $\mathrm{Ho}_{-} \mathrm{CR}$ or in $\mathrm{Hv}$ but not in $\mathrm{Ho}_{-} \mathrm{CS}$ (Figure 2H). Next we tested the properties of epithelial cells in aging and non-aging Hydra.

\section{Deficient autophagy inducibility in response to starvation in $\mathrm{Ho}$ CS}

We first tested the resistance to starvation of $\mathrm{Ho}_{-} \mathrm{CS}, \mathrm{Ho}_{-} \mathrm{CR}$, and $\mathrm{Hv}$ animals maintained at $18^{\circ} \mathrm{C}$ and noted the faster loss of pigmentation and progressive size decrease in Ho strains than in $H v$ animals that live twice longer (Figure_S3). However despite their similar survival rate, Ho_CS animals undergo a more dramatic reduction of their tissue layers than $\mathrm{Ho}_{-} \mathrm{CR}$, particularly the gastroderm (Figure 3A). As starved Hydra rapidly induces epithelial autophagy (Buzgariu et al. 2008; Chera et al. 2009), we analyzed autophagosome formation by anti-LC3B immunostaining. The ubiquitin-like protein ATG8/LC3 is an essential component of autophagosomes (Birgisdottir et al. 2013), present as four copies in Hydra (LC3A/B, LC3C, GABARAPL1, GABARAPL2), all expressed at high levels in ESCs (Figure_S4). In 18 ${ }^{\circ} \mathrm{C}-$ maintained animals we detected typical LC3+ vacuoles after one-day starvation (Figure 3B). After 17 starvation days their number doubles in $\mathrm{Hv}$ and $\mathrm{Ho}_{-} \mathrm{CR}$ animals, but not in $\mathrm{Ho}_{-} \mathrm{CS}$ where their size tends to enlarge (Figure 3C). In cold-maintained Ho_CS animals, neither the size, nor the number of autophagosomes significantly increases during aging, suggesting that autophagy regulation is deficient in Ho_CS. We also tested the Ulk1 inhibitor SBI-0206965 (Egan et al. 2015) that did not affect animal survival (Figure_S3C).

\section{Deficient autophagy activation in response to proteasome inhibition in Ho_CS}

Autophagy, which plays a crucial role in proteostasis, is up-regulated upon proteasome inhibition (Lan et al. 2015). To test the response to proteasome inhibition, we exposed animals to MG132 either continuously over six days, or as a 16 hour pulse (Figure 3D, Figure_S3D). In both conditions, Ho_CS animals rapidly show signs of toxicity, far before $\mathrm{Ho}_{-} \mathrm{CR}$ and $\mathrm{Hv}$ animals, suggesting a lower efficiency in compensatory autophagy. To visualize the autophagy flux, we used the mCherry-eGFP-LC3 sensor (Pankiv et al. 2007), designed to anchor mCherry and eGFP in early and mature autophagosomes, while the $\mathrm{pH}$-sensitive GFP fluorescence gets lost after lysosome fusion. Animals electroporated for transient epithelial expression were live imaged two days later. In $H v$ animals, the GFP fluorescence of most mCherry-GFP-hyLC3 puncta persists in untreated animals but vanishes within 75 minutes after MG132 exposure, indicating an efficient activation of the flux (Figure 3E). We noted a similar MG132-dependent activation of the autophagy flux in $\mathrm{Ho}_{-} \mathrm{CR}$ but not in Ho_CS epithelial cells where the fluorescence is diffused and the rare mCherry-GFP-hyLC3 puncta remain stable in the presence of MG132. These in vivo assays confirm the poor inducibility of the autophagy flux in Ho_CS.

\section{Differential regulation of Ulk1 activity in $\mathrm{Hv}, \mathrm{Ho} \_\mathrm{CR}$ and $\mathrm{Ho}$ CCS}

Two main nutrient sensing pathways, TORC and AMPK, regulate the entry into autophagy through the Ulk1 kinase complex, which once activated, phosphorylates components of the Beclin-1 complex that initiates autophagosome formation (Figure 3F) (Russell et al. 2013). To investigate Ulk1 activity in Hydra extracts, we first measured in vitro the phosphorylation level of human Beclin-1 at Ser15, a phosphorylation site conserved in Hydra Beclin-1 (Russell et al. 2013; Egan et al. 2015). As Ulk1 activity was undetectable in Hydra extracts (not shown), we used Hydra extracts to monitor the activity of Ulk repressors: Hydra extracts produced from daily fed or 9-day starved animals maintained at $18^{\circ} \mathrm{C}$ were coincubated with the recombinant human Ulk1 and Beclin-1 proteins. Hv extracts exhibit a low repressive activity on Ulk1 activity, while, as expected, $H_{0}$ CR extracts from fed animals inhibit Ulk1 activity more strongly than extracts from starved ones (Figure 3G, compare red and blue frames). By contrast, extracts prepared from starved Ho_CS animals show a limited Ulk1 derepression when compared to extracts from fed animals. These results point to a similar constitutive repression of Ulk1 activity in both Ho strains when compared to $H v$. However Ulk1 activity appears derepressed in Ho_CR animals submitted to starvation but not in Ho_CS ones. In $H v$ and Ho strains, a 16 hours MG132 treatment only slightly modifies Ulk1 inhibition (Figure $\mathbf{3 H}$, compare red and green frames), implying that MG132 enhances autophagy via a different path. 
bioRxiv preprint doi: https://doi.org/10.1101/236638; this version posted December 23, 2017. The copyright holder for this preprint (which was not certified by peer review) is the author/funder, who has granted bioRxiv a license to display the preprint in perpetuity. It is made available under aCC-BY-NC-ND 4.0 International license.

Tomczyk et al.

Deficient autophagy and aging in Hydra
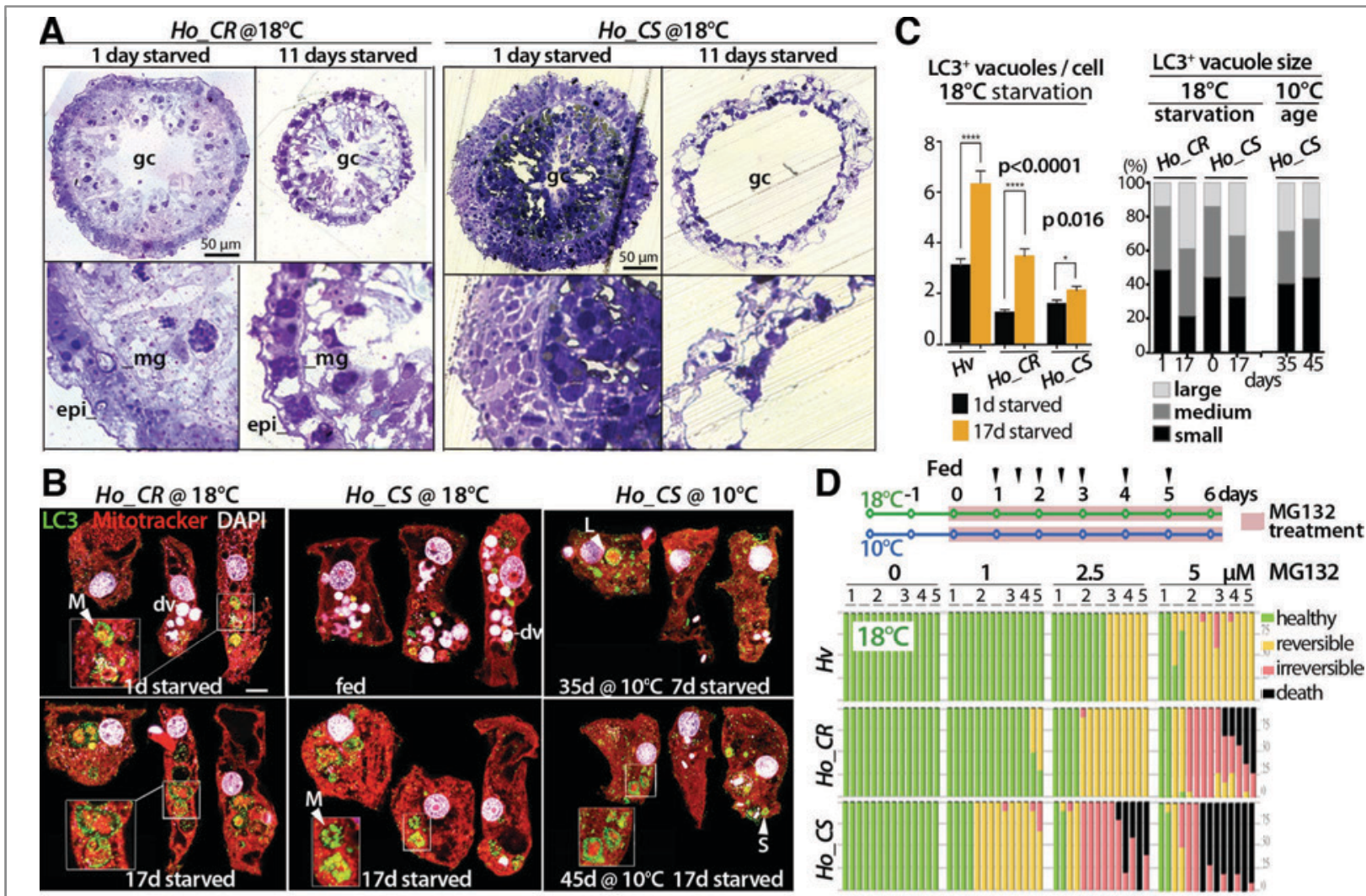

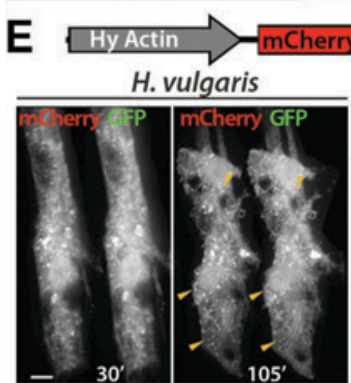

$\mathbf{F}$

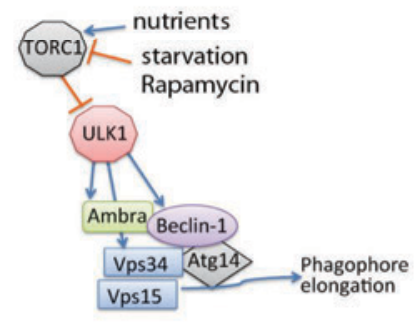

Ulk1 phospho-site

MEGSKTSNASTMQVSFVCQRCSQPLKLDTSFKILD human(S15) --TSMNGSKDTTHVS̈FLCQECYQPLRIDTSLYSLD Hydra (S24) MSEAEKOAVS̈FACQRCLQPIVLDEQLEKIS Droso(S10)
MTTQRS̄HICLNCOHPLRLDFTORRPD C eleg.(S6) MRKEEIPDKS̄RTIPIDPNLPKWVCQNCHHS Arabid. (S10)

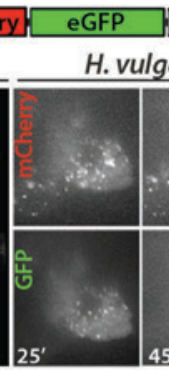

G

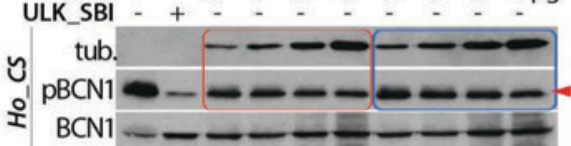

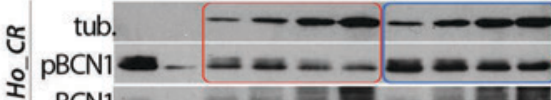
$\mathrm{BCN} 1-\ldots-\ldots-2 \mathrm{E}$

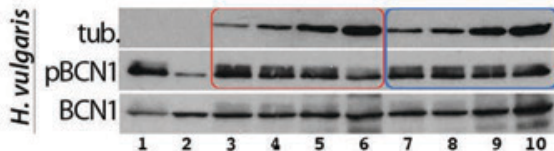

C LC3+ vacuoles/cell $\quad$ LC3 $3^{+}$vacuole size $18^{\circ} \mathrm{C}$ starvation $\frac{18^{\circ} \mathrm{C}}{\text { starvation }} \frac{10^{\circ} \mathrm{C}}{\text { age }}$

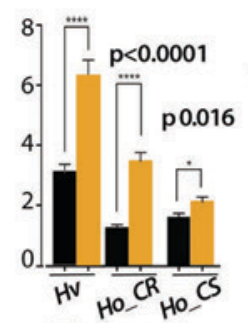
$\mathrm{HW}^{\mathrm{H}} \mathrm{HO}^{\mathrm{CR}} \mathrm{HO}^{\mathrm{C}} \mathrm{C}$ 1d starved 1d starved

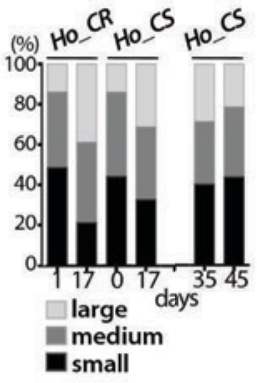

Ho CS + MG132

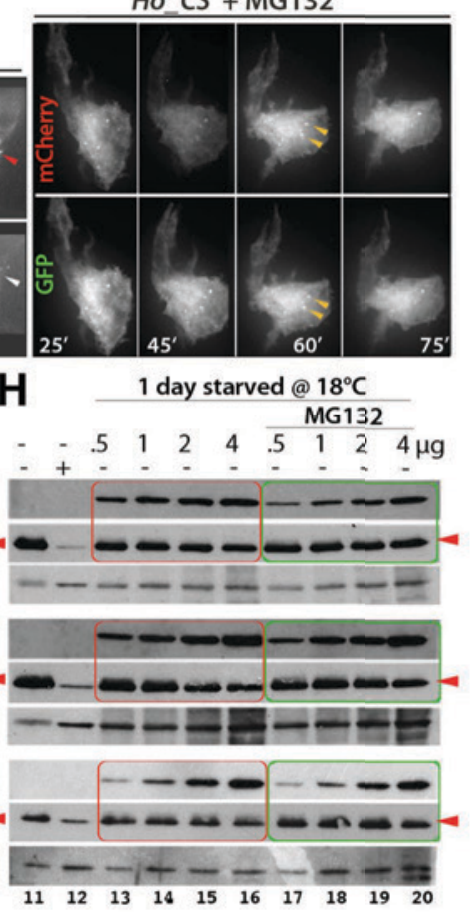

Figure 3: Deficient inducibility of the autophagy flux in Ho_CS animals

(A) Toluidine-stained transversal sections of gastric regions from fed and starved animals. Lower panels correspond to enlarged areas of above panels; epi: epidermis, gc: gastric cavity, mg: mesoglea. (B) Detection of large (L), medium (M) and small (S) autophagic vacuoles (av, arrowheads) and digestive vacuoles (dv, pink) in epithelial cells immunodetected for LC3 (green) and stained with mitotracker (red) and DAPI (white). (C) Number (left) and size (right) of LC3+ vacuoles counted in at least 100 ESCs per condition, $p$-values calculated using unpaired t-test. (D) Toxicity recorded in animals $(n=$ $2 \times 10 /$ strain) maintained at $18^{\circ} \mathrm{C}$ (left) or $10^{\circ} \mathrm{C}$ (right) and continuously exposed to the proteasome inhibitor MG132 at indicated concentrations. (E) Live imaging of ESCs transiently expressing the mCherry-eGFP-hyLC3A/B autophagy sensor in animals maintained at $18^{\circ} \mathrm{C}$ either untreated or exposed from to onwards to MG132 $5 \mu \mathrm{M}$. (F) Scheme showing the TORC1 regulation of the Beclin-1 complex via Ulk1 phosphorylation and the conservation of the Ulk1 phospho-site in Beclin-1. (G, H) In vitro kinase assays testing the activity of Hydra extracts prepared from animals, either fed or starved (G), treated or not with MG132 for 16 hours $(\mathbf{H})$ on Ulk1-dependent phosphorylation of human Beclin-1 at Ser15. 
bioRxiv preprint doi: https://doi.org/10.1101/236638; this version posted December 23, 2017. The copyright holder for this preprint (which was not certified by peer review) is the author/funder, who has granted bioRxiv a license to display the preprint in perpetuity. It is made available under aCC-BY-NC-ND 4.0 International license.

Tomczyk et al.

Deficient autophagy and aging in Hydra

\section{Differential regulation of the autophagy genetic program in $\mathrm{Ho}$ C $\mathrm{CR}$ and Ho_CS}

Next we analyzed how autophagy genes respond to cold induction by analyzing in $\mathrm{Ho}$ animals maintained at $18^{\circ} \mathrm{C}$ or $10^{\circ} \mathrm{C}$ the RNA-seq expression profiles of 74 genes linked to autophagy (Figure_S5, Figure_S6, Table-S1). We found 50 genes specifically regulated at $10^{\circ} \mathrm{C}, 34 / 50$ transiently up-regulated in both strains but 20/34 delayed by 10 days in $H_{0}$ CS when compared to Ho_CR, 5/50 up-regulated in Ho_CR but poorly in Ho_CS (AMBRA1, ATG16L1, BECN1, RAB24, VAMP7), 4/50 transiently upregulated in Ho_CS but poorly in Ho_CR (ATG2B, ATG4C, PLEKHF2, TOLLIP), 7/50 up-regulated at late time-points in Ho_CS (ATG4B, ATG7, CALRC, DAPK1, LAMP1, NBR1, p62/SQSTM1). These profiles suggest deficiencies at several levels of the autophagy flux in Ho_CS when compared to Ho_CR. The lack of regulation in Ho_CS of Ambra1 and Beclin-1 points to a deficient initiation of phagosome formation after cold transfer, while the stronger up-regulation in Ho_CS of Ulk1/2 and Atg13, two components of the Ulk1 complex crucial for Beclin-1 complex activation, possibly reveals a regulatory feedback loop mechanism. In agreement with a deficient initiation, we noted the delayed up-regulation of ATG4B, encoding a protease involved in LC3 cleavage and maturation, essential for autophagosome elongation. Also deficient in Ho_CS, the upregulation of Rab24, a small GTPase required for terminating starvationindependent autophagy (Yla-Anttila et al. 2015). Finally the late upregulation in Ho_CS of NBR1 and p62/SQSTM1 that encode autophagic cargo receptors (Bjorkoy et al. 2005; Johansen and Lamark 2011), likely reflects a blockade of the autophagy flux. Indeed p62/SQSTM1 is an evolutionarily-conserved protein that accumulates when its cargo is not properly degraded. In Hydra p62/SQSTM1 is ubiquitously expressed, predominantly in epithelial cells, steadily accumulating during aging (Figure_S7), providing an additional evidence for an inefficient autophagic flux in $H_{-}$CS.

\section{Anti-aging effect of Rapamycin in Ho_CS}

Rapamycin acts as a potent inhibitor of MTORC1 (Mechanistic Target of Rapamycin Complex 1), a complex that prevents autophagy. Consequently, Rapamycin enhances autophagy, thus promoting resistance to starvation (Shen and Mizushima 2014) and prolongs lifespan in multiple species, including yeast and mice (Fontana et al. 2010). To test the effect of Rapamycin treatment on aging Ho_CS, we continuously exposed the animals to Rapamycin from day-2 after transfer to $10^{\circ} \mathrm{C}$. We noted a prolonged maintenance of animal fitness as observed at day-58 (Figure 4A), a time when Ho_CS animals are severely degenerated with no visible head structures, while most Rapamycin-treated ones still harbor tentacles, contract and survive several weeks longer (Figure 4B). Also Rapamycin treatment dramatically improves regeneration in aging Ho_CS animals (Figure_S9A). Thus Rapamycin provides sustained antiaging benefits in Ho_CS animals. Nevertheless Rapamyin changes testis morphology in both strains, with testes exhibiting a flatten shape and containing fewer mature sperm cells (Figure 4C, Figure_S9B).

Next we tested whether Rapamycin promotes epithelial proliferation as on histological sections, we noted a thicker gastroderm in Rapamycin-treated animals (Figure 4C). During cold exposure, cycling activity remains rather stable in $\mathrm{Ho}_{-} \mathrm{CR}$ animals but progressively declines in $\mathrm{Ho}_{-} \mathrm{CS}$ ones, from $40 \%$ cycling cells at day- 0 to $5 \%$ at day-25, although slightly recovering later (Figure 4D). Similarly after HU treatment at $18^{\circ} \mathrm{C}$, cell cycling remains roughly stable in $\mathrm{Ho}_{-} \mathrm{CR}$ although transiently reduced at day-17, while becoming irreversibly reduced in $\mathrm{Ho}_{-} \mathrm{CS}$ animals. We also noted a delayed activation of a large subset of cell cycle genes in Ho_CS compared to Ho_CR (not shown), in agreement with the inability of Ho_CS animals to restore and maintain epithelial proliferation after i-cell loss. In Rapamycin-treated Ho_CS animals maintained at $10^{\circ} \mathrm{C}$, stem cell proliferation also dramatically declines but is rescued at day-35 and day-45 (Figure 4E). Hence Rapamycin might delay aging by restoring epithelial proliferation after icell loss.

\section{Rapamycin does not enhance the autophagy flux in Ho_CS}

Next we tested the regulation of the autophagy flux in $H_{0}$ CS animals exposed to Rapamycin. The in vivo analysis showed, as with MG132, a rapid flux activation after Rapamycin exposure in $H v$ and Ho_CR but not in Ho_CS cells, where we found the mCherry-eGFP-LC3A/B fluorescence predominantly cytoplasmic and the rare mCherry+/GFP+ puncta persisting after Rapamycin exposure (Figure 4F). Accordingly the number of LC3-positive vacuoles is not modified upon Rapamycin (Figure 4G). By quantitative proteomics 
bioRxiv preprint doi: https://doi.org/10.1101/236638; this version posted December 23, 2017. The copyright holder for this preprint (which was not certified by peer review) is the author/funder, who has granted bioRxiv a license to display the preprint in perpetuity. It is made available under aCC-BY-NC-ND 4.0 International license.

Tomczyk et al.

Deficient autophagy and aging in Hydra
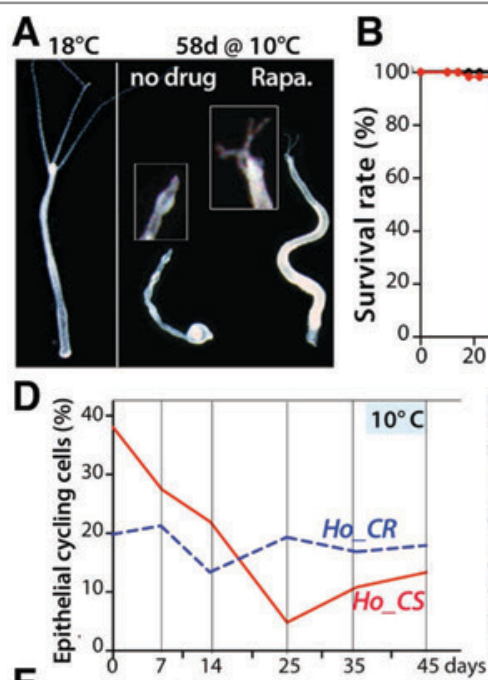

$\mathbf{F}$ H. vulgaris + Rapamycin
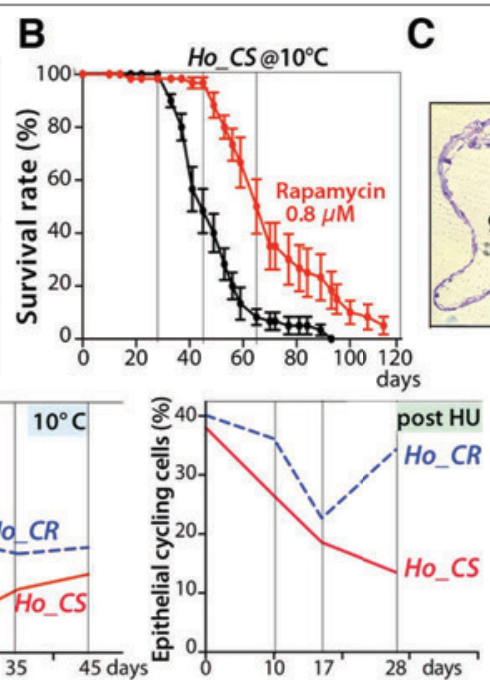

Ho $C R+$ Rapamycin
C

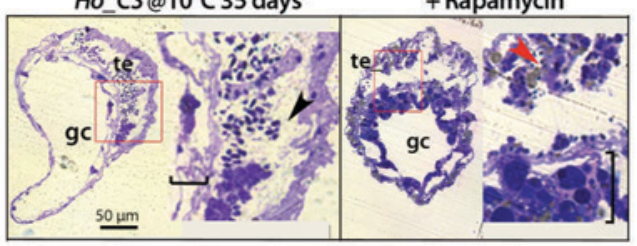

E

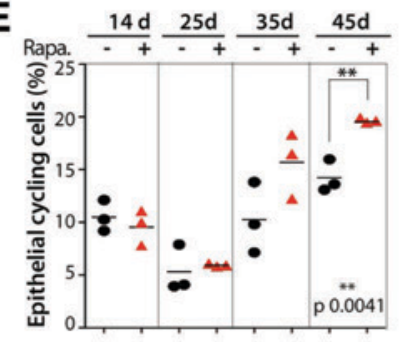

Ho CS + Rapamycin

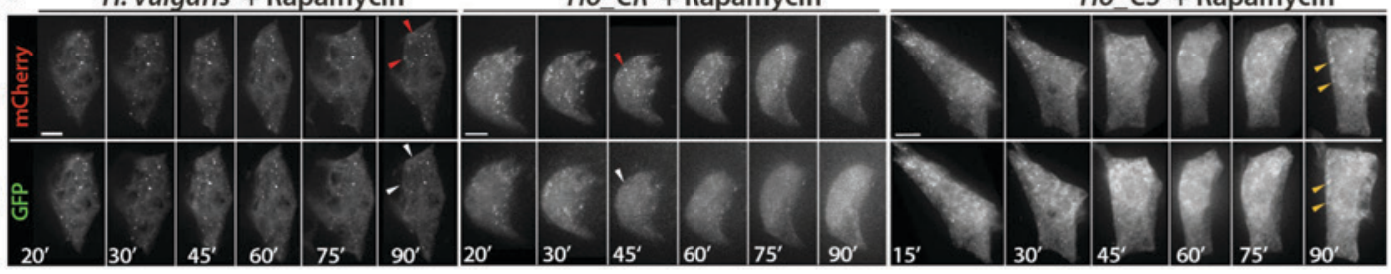

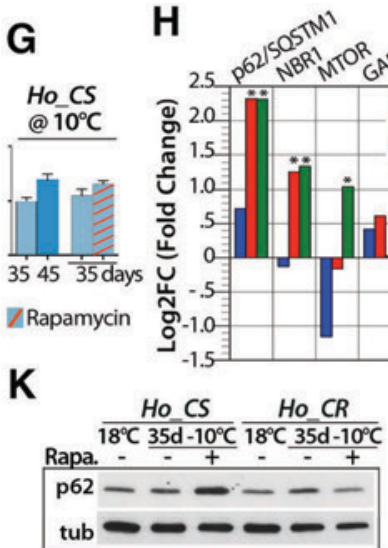

M

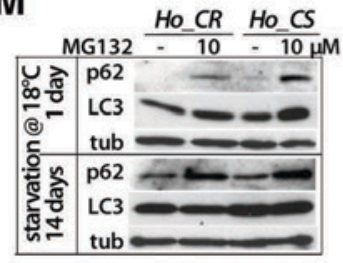

\section{I} Hup62 LIR KIR

J

$$
\text { J }
$$

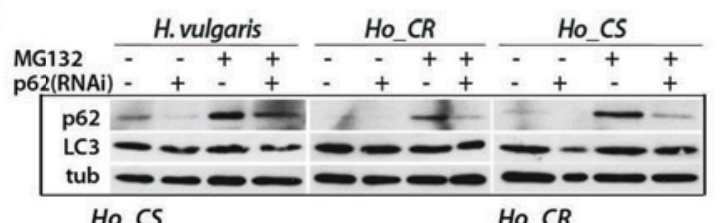

Ho_CS Ho CR
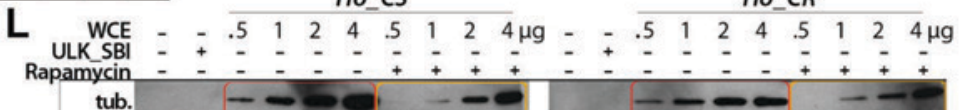

BCN1 $-\frac{-}{3}-\frac{-}{5} \frac{-}{7}-\frac{-}{9}-\frac{-1}{10}-\frac{-}{15}-\frac{-}{17}-$

N

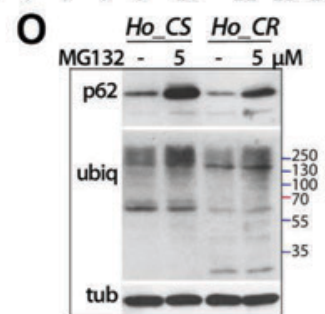

Figure 4: Rapamycin treatment delays aging in Ho_CS without enhancing the autophagy flux

(A) Aging morphological phenotype and (B) survival rates measured in Ho_CS animals exposed or not to Rapamycin from day- 3 at $10^{\circ} \mathrm{C}$. (C) Toluidine-stained transversal sections of gastric regions from Ho_CS animals maintained at $10^{\circ} \mathrm{C}$ for 35 days exposed or not to Rapamycin. Red squares: enlarged areas shown on the right of each panel; gc: gastric cavity, te: testis; brackets: thickness of the gastroderm; black arrowhead: sperm cells in the testis lumen; red arrowhead: sperm cells engulfed in an epithelial cell. (D, E) BrdU-labeling index values measured after 96 hours BrdU exposure (BLI-96) in animals maintained at $10^{\circ} \mathrm{C}(\mathrm{D}$, left), HU-treated (D, right), or in Ho_CS treated or not with Rapamycin (E). In $\mathrm{D}$, different BLI values at to are due to differences in the feeding diet the two previous weeks (Ho_CS: 4x/week, Ho_CR: 2x/week). (F) Live imaging of epithelial cells transiently expressing the mCherry-eGFP-hyLC3A/B autophagy sensor in animals maintained at $18^{\circ} \mathrm{C}$ and exposed to Rapamycin $(0.8 \mu \mathrm{M})$ from to. (G) Number of LC3-positive vacuoles counted in at least 100 ESCs of Ho_CS maintained at $10^{\circ} \mathrm{C}$ treated or untreated with Rapamycin, p-values calculated using unpaired t-test. (H) Proteomic analysis performed on Ho_CS animals maintained for 35 days at $18^{\circ} \mathrm{C}$ or at $10^{\circ} \mathrm{C}$ exposed or not to Rapamycin for 32 days, ${ }^{*}: 0.05,{ }^{* *}: 0.001$ significance. (I) Structure of the human and Ho p62/SQSTM1 (p62) proteins (see alignment in Figure_S8). The black bar indicates the region used to raise an anti-Hydra p62 antibody. (J) p62 levels in animals RNAisilenced for p62 and exposed or not to MG132 for 16 hours; tub: $\alpha$-tubulin. (K) p62 levels in animals treated or not with Rapamycin. (L) In vitro kinase assays testing the activity of Hydra extracts prepared from animals treated or not with Rapamycin for 13 days on Ulk1-dependent phosphorylation of human Beclin-1. (M) p62 and LC3 levels in animals starved for 14 days or not, and exposed to MG132 or not for 16 hours. (N, O) p62 levels and ubiquitin patterns in animals maintained at $18^{\circ} \mathrm{C}$ and exposed to MG132 or not for 16 hours at indicated conditions. 
bioRxiv preprint doi: https://doi.org/10.1101/236638; this version posted December 23, 2017. The copyright holder for this preprint (which was not certified by peer review) is the author/funder, who has granted bioRxiv a license to display the preprint in perpetuity. It is made available under aCC-BY-NC-ND 4.0 International license.

Tomczyk et al.

Deficient autophagy and aging in Hydra

we also detected p62/SQSTM1 up-regulated 1.6x in 35-day old Ho_CS animals and 5.6x in Rapamycintreated ones (Figure $4 \mathbf{H}$ ). We raised an antibody against the p62/SQTSM1 C-terminus (Figure 4I, Figure_S8), validated its specificity on extracts from animals silenced for p62/SQSTM1 (Figure 4J), confirmed its up-regulation when aging and Rapamycin are combined (Figure 4K) and showed its colocalization with LC3+ autophagosomes (Figure_S9d, Movie S3). The Ulk1 kinase assays testing extracts from animals maintained at $10^{\circ} \mathrm{C}$ for 13 days, exposed or not to Rapamycin, show a derepression of Ulk1 activity by Ho-CR extracts, and a partial one by Ho-CS extracts (Figure $4 \mathbf{L}$ ). This suggests that Rapamycin only partially counteracts the Ulk1 repressor identified in Ho_CS extracts. In animals maintained at $18^{\circ} \mathrm{C}$, starvation and MG132 exposure also lead to p62/SQSTM1 accumulation, higher in $\mathrm{Ho}_{-} \mathrm{CS}$ than in $\mathrm{Ho}_{-} \mathrm{CR}$ (Figure 4M), together with an accumulation of polyubiquitinated proteins, constitutively more abundant in $\mathrm{Ho}_{-} \mathrm{CS}$ than in $\mathrm{Ho}_{-} \mathrm{CR}$ (Figure $4 \mathrm{~N}, \mathbf{4 0}$, Figure_S9C). Hence, the enhanced p62/SQSTM1 accumulation in Ho_CS, whatever the autophagy inducer(s), confirms that the autophagy flux remains deficient in Rapamycin-exposed Ho_CS animals.
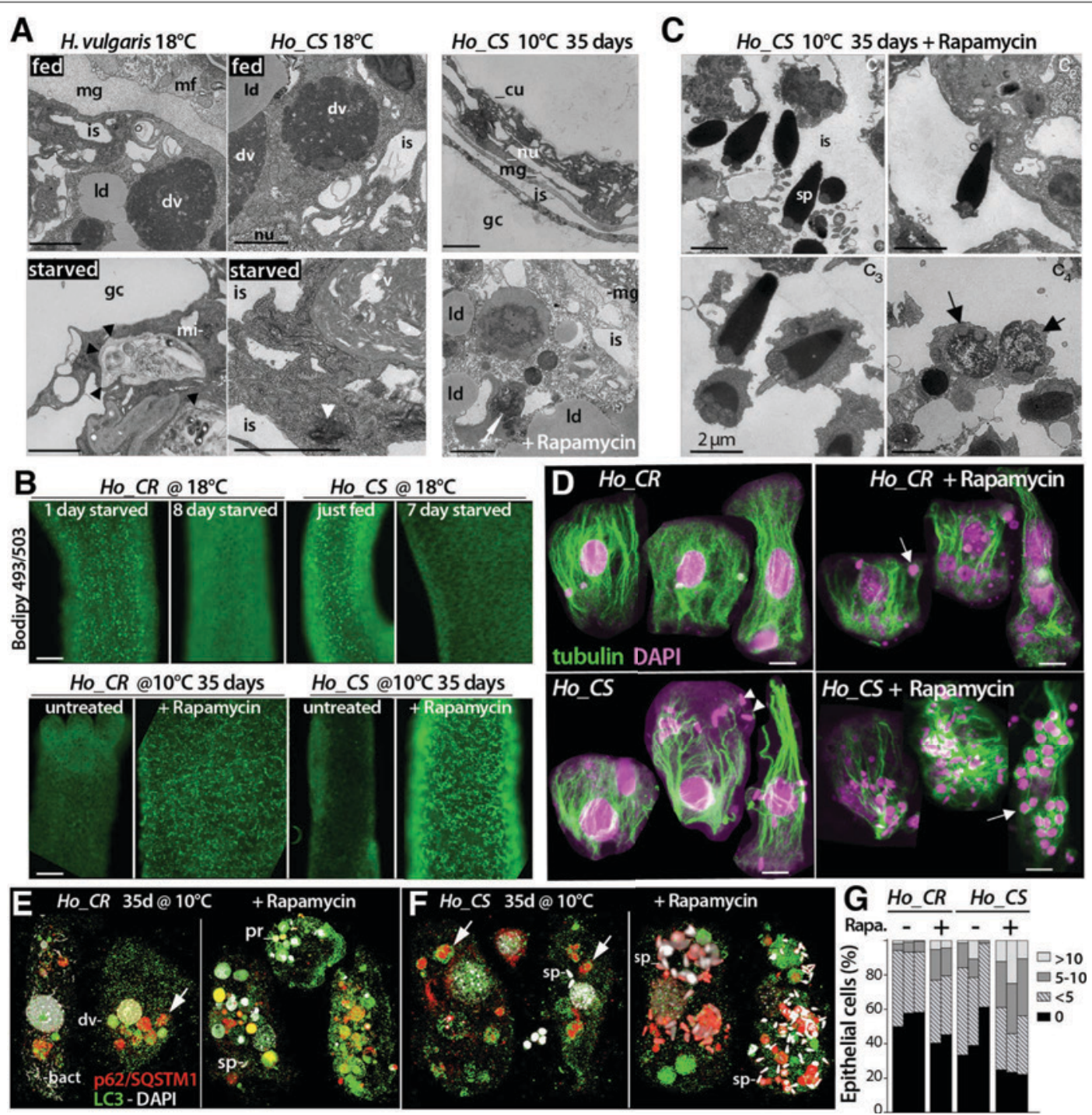

Figure 5: Rapamycin promotes epithelial phagocytosis and lipid droplet formation in Hydra

(A) TEM views of body column sections from $\mathrm{HV}$ and Ho_CS animals maintained as indicated. Black arrowheads: autophagosome, white arrowhead: aggregate, white arrow: engulfed corpse. (B) Detection of lipid droplets in live animals stained with Bodipy 493/503. (C) Sperm cells (sp) engulfed in epithelial cells from Rapamycin-treated Ho_CS animals maintained at $10^{\circ} \mathrm{C}$ for 35 days, detected in the intracellular space (is, c1, c2), surrounded by cytoplasm (c3) and digested (c4). Black arrows: mitochondria at the base of sperm cells, white arrowheads: sperm nuclei. (D) Engulfed cells detected with an anti a-tubulin antibody (green) and DAPI staining (pink) in Ho_CS and Ho_CR epithelial cells at day-36 after cold transfer. Arrows point to immature germ cells and arrowheads to sperm cells. (E, F) Engulfed cells immuno-detected with the anti-Hydra p62/SQSTM1 (red) and the anti-human LC3 (green) antibodies, co-stained with DAPI (white). Arrows point to p62-labeled granules associated or not with LC3. Abbreviations: cu: cuticle, dv: digestive vacuole, gc: gastric cavity, is: intracellular space, ld: lipid droplets, mf: myofibril, mg: mesoglea, mi: mitochondria, nu: nucleus, pr: progenitors, $\mathrm{sp}$ : $\mathrm{sperm}$ cells. Scale bars $=2(\mathrm{a}, \mathrm{b}), 10(\mathrm{~d}, \mathrm{e}, \mathrm{f}), 100$ (c) $\mu \mathrm{m}$. (G) Number of engulfed cells per epithelial cell at day-36 after cold transfer, counted in four categories: $>10,5-10,<5,0$ per cell. Each condition in triplicates (117-249 cells per sample). 
bioRxiv preprint doi: https://doi.org/10.1101/236638; this version posted December 23, 2017. The copyright holder for this preprint (which was not certified by peer review) is the author/funder, who has granted bioRxiv a license to display the preprint in perpetuity. It is made available under aCC-BY-NC-ND 4.0 International license.

Tomczyk et al.

Deficient autophagy and aging in Hydra

\section{Rapamycin promotes epithelial phagocytosis and lipid droplet accumulation}

To further investigate how Rapamycin delays aging in Hydra, we analyzed tissue sections and noticed that epithelial phagocytosis is strongly enhanced upon Rapamycin (Figure 5). In regularly-fed animals maintained at $18^{\circ} \mathrm{C}$, epithelial cells contain a dense cytoplasm, numerous mitochondria, few intracellular spaces, and numerous digestive vacuoles. After 11 starvation days, mitochondria become sparse while numerous intracellular spaces appear, as well as autophagosomes in $H v$ animals, i.e. double-membrane vacuoles with a heterogeneous content; such vacuoles are rare in Ho_CS animals (Figure 5A). After 35 days at $10^{\circ} \mathrm{C}$, cells from Rapamycin-treated Ho_CS animals display a reduced cytoplasm, large intracellular spaces and sparse autophagosomes, but numerous electron lucent vacuoles resembling lipid droplets, as confirmed by Bodipy 493/503 labeling (Figure 5B). We also identified numerous sperm cells in the epithelial intracellular spaces, internalized in the cytoplasm and finally digested (Figure 5C, 5D). Rapamycin-induced epithelial phagocytosis is also visible in $\mathrm{Ho}_{-} \mathrm{CR}$ animals, with intracellular germ cells visible besides the digestive vacuoles (Figure 5D, 5E). These phagocytized cells, numerous at day-35, are frequently surrounded by a thick p62+ rim, often co-localizing with LC3 (Figure 5E, Figure_S9D-H, Movie-S2), already detected at day-9 post-transfer (Figure_S9G). At day-9, the Rapamycin-enhanced epithelial phagocytosis is not restricted to germ cells as numerous phagocytized small cells, typically nematoblasts or nematocytes can be detected (Figure_S9G). The quantification of this engulfment process shows a Rapamycin-induced phagocytosis maximal at day-36, markedly higher in Ho_CS than in Ho_CR (Figure 5G, Figure_S9E). For animals maintained at $18^{\circ} \mathrm{C}$, the chronic exposure to Rapamycin was too toxic to detect any effect (not shown). All together, these results indicate that Rapamycin dramatically enhances the phagocytic behavior of epithelial cells in both Ho_CS and Ho_CR, likely providing a source of exogenous nutrients that promote animal survival in Ho_CS.

\section{Efficient autophagy is required for fitness and survival in $\mathbf{H}$. vulgaris.}

To test whether a blockade of the autophagy flux promotes aging in non-aging $H v$ animals, we disrupted autophagosome formation by knocking-down WIPI2, which recruits the Atg12-5-16L1 complex, critical for LC3 conjugation (Figure 6A) (Dooley et al. 2014). Hydra WIPI2 possesses both the ATG16 and the PI3P binding motifs necessary for its function (Figure 6B, Figure_S10). To silence WIPI2, we repeatedly electroporated (EP) $H v$ polyps with siRNAs (Figure 6 C) and noted after EP-6 a $80 \%$ reduction in WIPI2 transcript level (Figure 6D). Consistent with a deficient autophagic flux, we found the p62/SQSTM1 protein level twice higher in WIPI2(RNAi) animals (Figure 6D). We also noted a lower number of LC3 puncta in epithelial cells of WIPI2(RNAi) animals, where LC3 signals are diffuse and cytoplasmic even in the presence of MG132 (Figure 6E, 6F), similar to the LC3 pattern observed in Ho_CS epithelial cells. In MG132-treated cells of control(RNAi) animals, the number of LC3 puncta is quite stable, consistently with a robust induction of autophagy (Figure 6F). At the phenotypic level, we noted the size decrease of WIPI2(RNAi) animals after EP-7, and their apical disorganization (Figure 6G). About $60 \%$ of these animals died within the two following weeks, while no mortality was observed in control(RNAi) animals (Figure 6H). Control(RNAi) animals bisected at mid-gastric level after EP-6 regenerated normally their head, while about $30 \%$ animals WIPI2(RNAi) animals show a delayed or blocked regeneration (Figure 6I). Moreover, the WIPI2(RNAi) animals having regenerated their head rapidly died, proving their lack of fitness (not shown). In summary, knocking-down WIPI2 suffices to block autophagy by impairing the loading of LC3 onto phagophores, resulting in the observed switch from punctuated to diffuse LC3 pattern. A prolonged autophagy blockade in the slow-aging $H v$ animals leads to a rapid loss of animal fitness, followed by animal death, mimicking the aging phenotype observed in Ho_CS animals. 
bioRxiv preprint doi: https://doi.org/10.1101/236638; this version posted December $23,2017$. The copyright holder for this preprint (which was not certified by peer review) is the author/funder, who has granted bioRxiv a license to display the preprint in perpetuity. It is made available under aCC-BY-NC-ND 4.0 International license.

Tomczyk et al.

Deficient autophagy and aging in Hydra
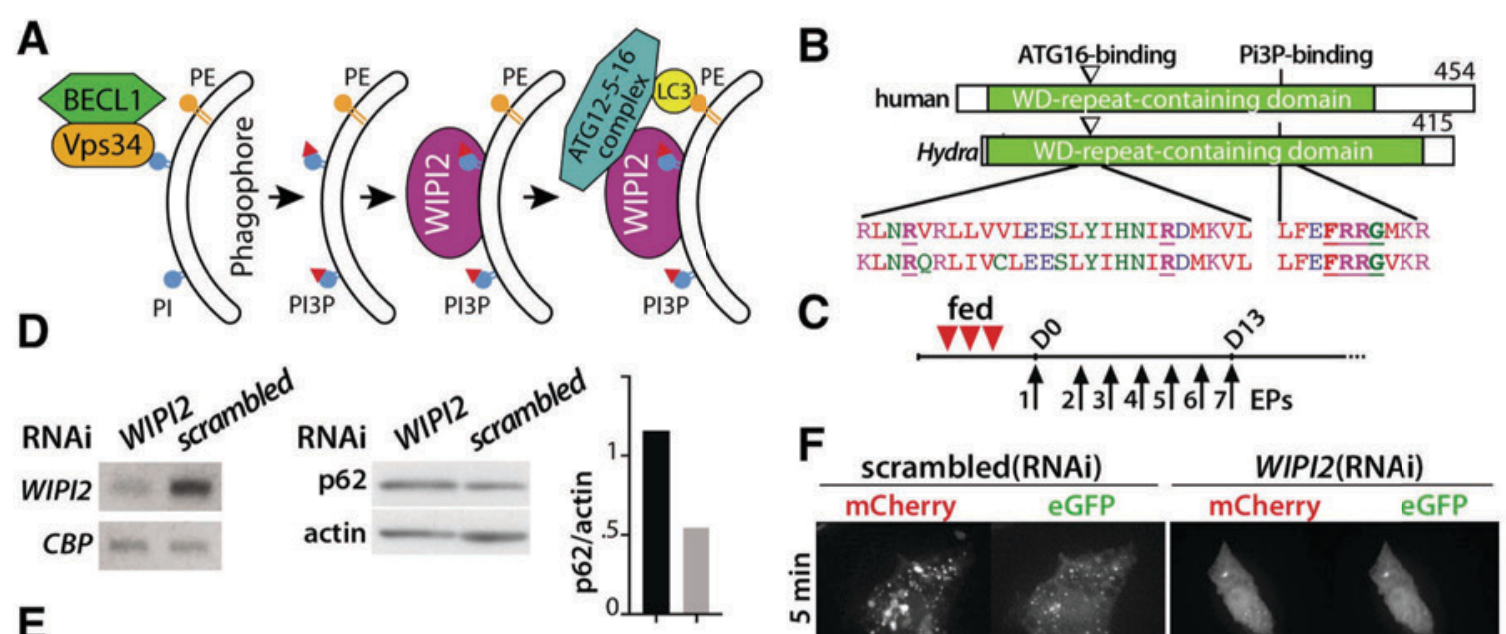

E
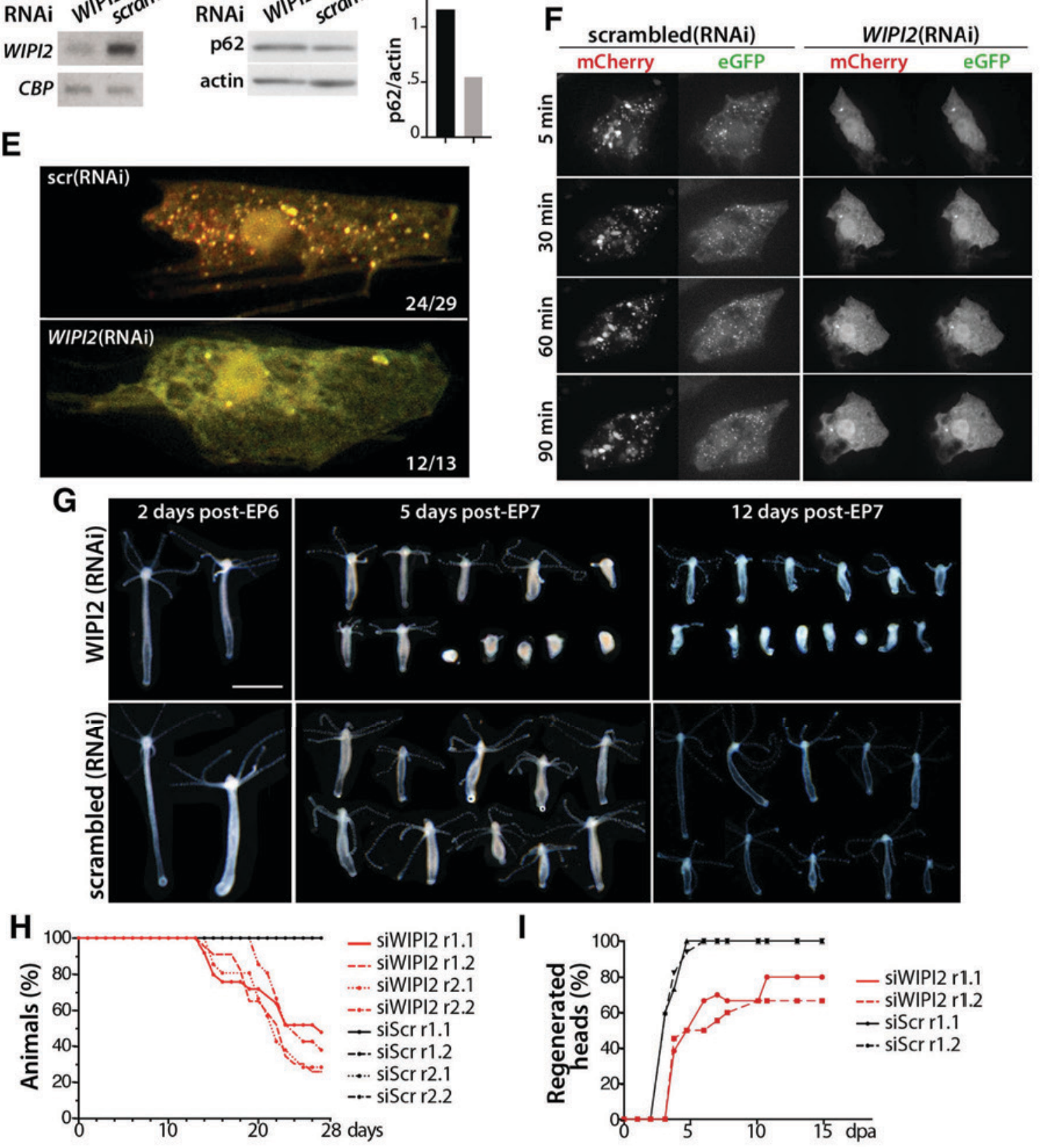

Figure 6: Impact of WIPI2 silencing on autophagic flux, survival, and regeneration in $\boldsymbol{H}$. vulgaris

(A) Scheme showing the role of WIPI2 in autophagosome formation(Dooley et al. 2014). (B) Structure of the human and Hydra WIPI2 proteins and alignment of the regions involved in ATG12-5-16 complex and PI3P binding. (C) RNAi silencing procedure performed on intact well-fed animals. Red arrowheads: feedings, black arrows: electroporation (EP). (D) WIPI2 and $C B P$ (CREB-binding protein) RNA levels (left) and p62 and actin protein levels (right) in $H v$ animals electroporated $6 x$ with WIPI2- or scrambled-siRNAs. (E, F) LC3 pattern detected in epithelial cells expressing the mCherry-eGFP-hyLC3 autophagy sensor two days after EP7 in WIPI2(RNAi) or scrambled(RNAi) animals. Note in (e) the lack of LC3 puncta in WIPI2(RNAi) cells. In (f) animals were exposed to MG132 at to. (G-I) Phenotypic analysis of WIPI2(RNAi) and scrambled(RNAi) animals : morphology after EP6 or EP7 $(\mathbf{G})$; mortality rates recorded after EP7 $(\mathbf{H})$; head regeneration after bisection performed at mid-gastric level 24 hours post-EP6 (I). Scale bar $=1 \mathrm{~mm}$. 
bioRxiv preprint doi: https://doi.org/10.1101/236638; this version posted December $23,2017$. The copyright holder for this preprint (which was not certified by peer review) is the author/funder, who has granted bioRxiv a license to display the preprint in perpetuity. It is made available under aCC-BY-NC-ND 4.0 International license.

Tomczyk et al.

Deficient autophagy and aging in Hydra

\section{DISCUSSION}

\section{Epithelial adaptability as a common basis for low senescence}

The aging phenotype in Ho_CS animals share features with mammalian aging, like loss of somatic stem cells, deterioration of the muscular network, alterations of the nervous system, behavioral alterations, global loss of health. This aging process results from epithelial deficiencies that prevent ESCs to adapt to environmental changes, rather than from direct negative effects of these changes (Figure 7). By contrast, $H v$ animals survive weeks of starvation, a period when their epithelial cells enhance their phagocytic behavior (Bosch and David 1984), activate an efficient autophagy program (Buzgariu et al. 2008; Chera et al. 2009) and reversibly slow-down cycling (Otto and Campbell 1977). Also Hv animals can become "epithelial", surviving for years (if manually fed) the elimination of their i-cells and nervous system (Marcum and Campbell 1978; Sugiyama and Fujisawa 1978), as their ESCs adapt their genetic program (Wenger et al. 2016). Therefore a robust epithelial adaptability to environmental conditions evidenced by changes in cell cycle, autophagy flux, gene expression, provides a necessary and sufficient framework for low senescence in $H$. vulgaris strains (Schenkelaars et al. 2018).

\section{Deficient response to proteotoxic stress in Hydra oligactis}

The maintenance of proteostasis is critical for longevity (Morimoto and Cuervo 2009; Kaushik and Cuervo 2015). In Hydra we identified three distinct levels of proteostasis efficiency: low in Ho_CS animals that are highly sensitive to proteasome inhibition, intermediate in $\mathrm{Ho}_{-} \mathrm{CR}$, and high in $\mathrm{Hv}$. As the ubiquitinproteasome and the lysosome-autophagosome are the two main systems that maintain proteome homeostasis (Pandey et al. 2007; Rubinsztein 2007; Lan et al. 2015), this observed difference in MG132 sensitivity between aging and non-aging Hydra strains supports the finding that deficient autophagy contributes to aging in Ho_CS. Also the molecular chaperone Hsp70, involved in protein folding, might explain the observed difference in proteostasis efficiency between $\mathrm{Hv}$ and Ho strains. Indeed, Hsp70 expression is up-regulated in both strains upon heatshock but in $\mathrm{Ho}$, transcripts are unstable and the protein not efficiently translated (Gellner et al. 1992; Brennecke et al. 1998). Thus as in yeast, Drosophila, C. elegans or mammals (Cuervo 2008) an efficient autophagy appears necessary to prevent aging in Hydra.

\section{Efficient epithelial autophagy is required for maintaining epithelial cell cycling in Hydra}

In $H v$ animals submitted to physiological starvation, numerous interstitial cells undergo apoptosis and are phagocytosed by the epithelial cells, a process supposed to sustain cell proliferation and animal survival (Bosch and David 1984). Here we identified a similar mechanism, where the autophagy deficiency identified in Ho_CS primarily causes aging, by reducing epithelial proliferation to a point where regeneration and animal survival are compromised. Ho_CR but not Ho_CS animals adapt and ultimately survive, as they induce an efficient autophagy that allows a sustained epithelial cell cycling. Three arguments support this scenario, (i) the correlation between epithelial self-renewal and autophagy levels observed in Ho_CS and Ho_CR animals that undergo gametogenesis at $10^{\circ} \mathrm{C}$; (ii) the rescue of epithelial cell cycling when Rapamycin-induced phagocytosis provides a source of nutrients; (iii) the aging process induced in $H v$ animals upon blockade of autophagy. Therefore autophagy seems to protect against aging by maintaining stem cell renewal. Similarly, in aging mammals, autophagy is crucial for the survival of hematopoietic stem cells (Warr et al. 2013; Gomez-Puerto et al. 2016), for the maintenance of muscle satellite cells (Garcia-Prat et al. 2016).

\section{The Rapamycin-induced engulfment behavior as a novel modulator of aging}

MTORC1 suppresses autophagy through several mechanisms (Wullschleger et al. 2006; Shen and Mizushima 2014) and its inhibition via the macrolide Rapamycin de-represses autophagy (Hosokawa et al. 2009). In aging Ho_CS animals, Rapamycin does not rescue the autophagy flux but rather promotes an enhanced engulfment behavior of the epithelial ectodermal cells, which digest the surrounding small cells including germ cells, a behavior rarely observed in untreated cells. This engulfment process resembles entosis in which live cells become engulfed within single-membrane LC3-associated vesicles (Florey et al. 2011) and then degraded thanks to the support of MTORC1 (Krajcovic et al. 2013), but also 
Deficient autophagy and aging in Hydra

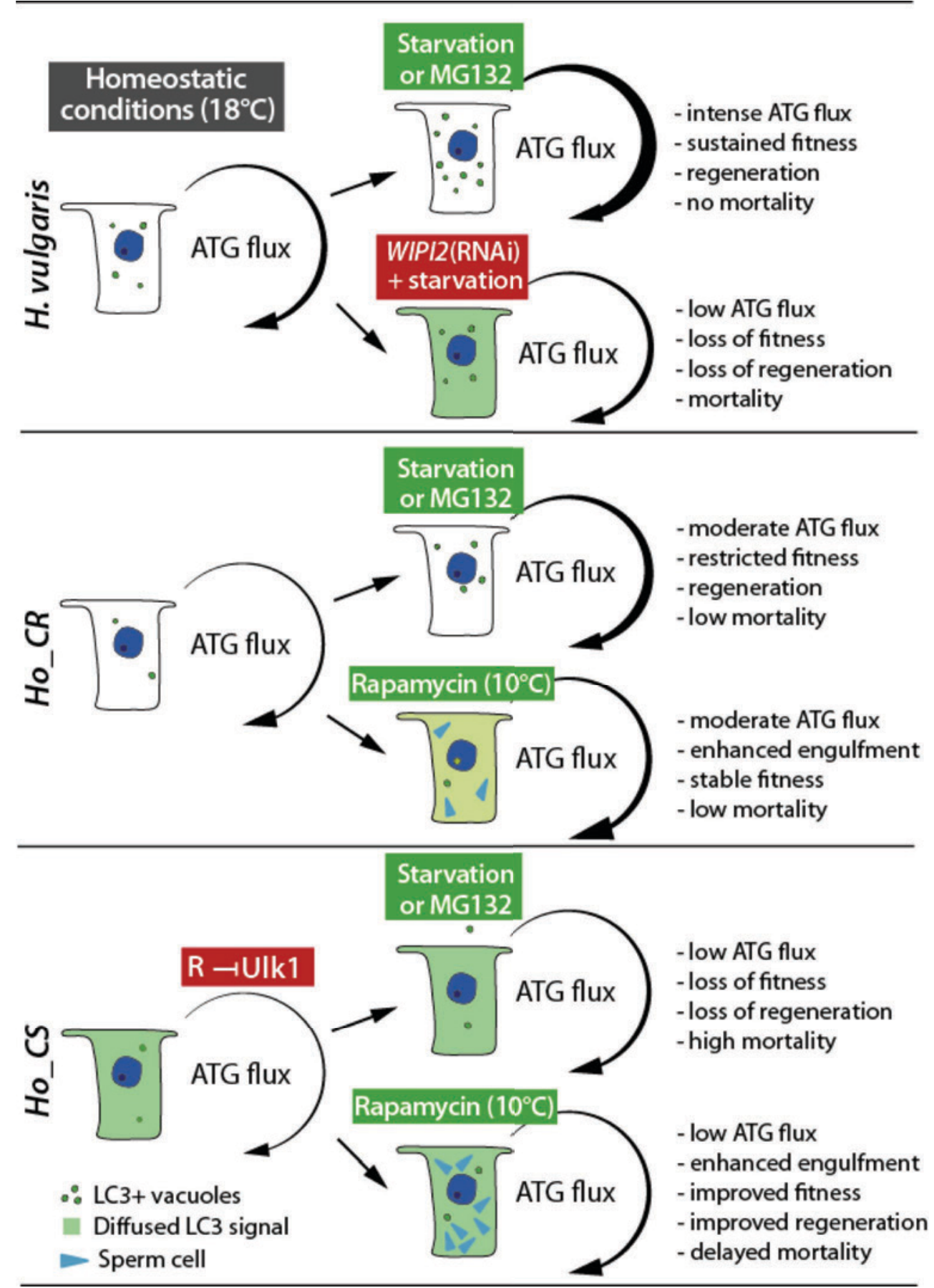

Figure 7: Summary view of the responsiveness of the autophagic flux in aging and non-aging Hydra

The responsiveness of the autophagy flux to starvation, MG132 or Rapamycin treatments was deduced from the formation of LC3-positive vacuoles, the accumulation of p62/SQSTM1 and the in vivo imaging of LC3 vacuoles in Hydra epithelial cells.

LC3-associated phagocytosis (LAP), where LC3 associates with single-membrane phagosomes containing pathogens (Sanjuan et al. 2007). A third possibility would be phagoptosis where viable cells that display "eat-me" signals or lose the "don't-eat-me" signals can be phagocytized (Brown and Neher 2012). The Rapamycin-induced increase in p62/SQSTM1 levels in aging animals and the thick p62/SQSTM positive rim surrounding most engulfed cells suggest that p62/SQSTM1 is involved in this engulfment process. Unfortunately the p62/SQSTM1(RNAi) knock-down was too partial to prevent the Rapamycin-induced accumulation of p62/SQSTM1 (Figure 4J). This beneficial Rapamycin-induced phagocytic behavior of epithelial cells is a new finding with no equivalent in any other system to our knowledge. If artificially promoted, it could rescue an active metabolism in cells where autophagy is 
bioRxiv preprint doi: https://doi.org/10.1101/236638; this version posted December 23, 2017. The copyright holder for this preprint (which was not certified by peer review) is the author/funder, who has granted bioRxiv a license to display the preprint in perpetuity. It is made available under aCC-BY-NC-ND 4.0 International license.

Tomczyk et al.

Deficient autophagy and aging in Hydra

deficient and thus act as a potent anti-aging mechanism. However Rapamycin may also delay the aging phenotype by reducing the amount of energy allocated to the germline.

\section{Complex regulation of Rapamycin-induced lipid droplet accumulation in Ho_CS}

Rapamycin treatment also leads to the production of abundant lipid droplets in Hydra epithelial cells, likely as a result of the nutrient inflow from the phagocytosed cells and/or by changes in lipid metabolism caused by MTORC1 inhibition (Thiam et al. 2013). In yeast, TORC1 inhibition promotes LD formation (Madeira et al. 2015) similarly to what is observed in Hydra. In addition, a chronic exposure to Rapamycin prevents the assembly of the TORC2 complex (Sarbassov et al. 2006), possibly modulating the lipid metabolism via TORC2. In C. elegans, knocking-down Rictor enhances the deposition of lipid storage via LD formation (Jones et al. 2009). More generally, Rapamycin increases the level of triacyl-glycerides as observed in Drosophila (Bjedov et al. 2010). As an alternative mechanism contributing to LD accumulation, the deficient autophagy characterized in Ho_CS might affect lipophagy, a selective type of autophagy that uses most components of the macroautophagy machinery. Hence several distinct mechanisms might contribute to the observed LD accumulation in Rapamycin-treated Ho_CS animals.

In summary, this study highlights the value of Hydra as a novel model system for aging studies, showing the impact of autophagy on the maintenance of an active stock of stem cells, and the beneficial anti-aging effect of daily exposure to Rapamycin including the maintenance of regeneration. These Rapamycin effects appear associated with energy recovery through digestion of engulfed cells, modulations of lipid metabolism, and proteostasis maintenance possibly via TORC2.

\section{SUPPLEMENTAL FILE}

Methods, 10 supplemental Figures, one Table and four Movies are available in the supplemental file.

\section{ACKNOWLEDGMENTS}

This research was supported by the National Institute of Health (grant R01AG037962), the Swiss National Science Foundation (SNF 31003A_149630, 31003_169930), the canton of Geneva. The authors thank H. Shimizu (NIG Mishima, Japan) who provided Ho_CS polyps, D. Chiappe and R. Hamelin from Proteomics Core Facility at EPFL, D. Benoni, C. Perruchoud and M-L. Curchod for excellent technical support, A-M. Cuervo, R. Loewith and T. Soldati for discussions and useful advices, R. Loewith and T. Lamark for helpful comments on the manuscript.

\section{AUTHOR CONTRIBUTIONS}

B.G., S.T., Q.S. and Y.W. designed the experiments and validated the results; S.T., Q.S., N.S., K.E., K.F., W.B. and C.B. performed the experiments; Y.W. and S.T. curated the transcriptomic and proteomic data; S.T., Q.S. produced the original draft, revised by S.A. and B.G. Funding was obtained by S.A. and B.G. B.G. supervised this study.

\section{REFERENCES}

Austad SN. 2009. Is there a role for new invertebrate models for aging research? J Gerontol A Biol Sci Med Sci 64: 192-194.

Birgisdottir AB, Lamark T, Johansen T. 2013. The LIR motif - crucial for selective autophagy. J Cell Sci 126: 32373247.

Bjedov I, Toivonen JM, Kerr F, Slack C, Jacobson J, Foley A, Partridge L. 2010. Mechanisms of life span extension by rapamycin in the fruit fly Drosophila melanogaster. Cell metabolism 11: 35-46.

Bjorkoy G, Lamark T, Brech A, Outzen H, Perander M, Overvatn A, Stenmark H, Johansen T. 2005. p62/SQSTM1 forms protein aggregates degraded by autophagy and has a protective effect on huntingtin-induced cell death. J Cell Biol 171: 603-614.

Bosch TC, David CN. 1984. Growth regulation in Hydra: relationship between epithelial cell cycle length and growth rate. Dev Biol 104: 161-171.

Brennecke T, Gellner K, Bosch TC. 1998. The lack of a stress response in Hydra oligactis is due to reduced hsp70 mRNA stability. Eur J Biochem 255: 703-709.

Brien P. 1953. La pérennité somatique. Biol Rev 28: 308-349. 
bioRxiv preprint doi: https://doi.org/10.1101/236638; this version posted December 23, 2017. The copyright holder for this preprint (which was not certified by peer review) is the author/funder, who has granted bioRxiv a license to display the preprint in perpetuity. It is made available under aCC-BY-NC-ND 4.0 International license.

Tomczyk et al.

Deficient autophagy and aging in Hydra

Brown GC, Neher JJ. 2012. Eaten alive! Cell death by primary phagocytosis: 'phagoptosis'. Trends Biochem Sci 37: 325-332.

Buzgariu W, Chera S, Galliot B. 2008. Methods to investigate autophagy during starvation and regeneration in hydra. Methods Enzymol 451: 409-437.

Buzgariu W, Crescenzi M, Galliot B. 2014. Robust G2 pausing of adult stem cells in Hydra. Differentiation 87: 83-99.

Chera S, Buzgariu W, Ghila L, Galliot B. 2009. Autophagy in Hydra: a response to starvation and stress in early animal evolution. Biochim Biophys Acta 1793: 1432-1443.

Cuervo AM. 2008. Autophagy and aging: keeping that old broom working. Trends Genet 24: 604-612.

Dooley HC, Razi M, Polson HE, Girardin SE, Wilson MI, Tooze SA. 2014. WIPI2 links LC3 conjugation with PI3P, autophagosome formation, and pathogen clearance by recruiting Atg12-5-16L1. Mol Cell 55: 238-252.

Egan DF, Chun MG, Vamos M, Zou H, Rong J, Miller CJ, Lou HJ, Raveendra-Panickar D, Yang CC, Sheffler DJ et al. 2015. Small Molecule Inhibition of the Autophagy Kinase ULK1 and Identification of ULK1 Substrates. Mol Cell 59: 285-297.

Finch CE. 1990. Longevity, senescence, and the genome. University of Chicago Press, Chicago.

Florey O, Kim SE, Sandoval CP, Haynes CM, Overholtzer M. 2011. Autophagy machinery mediates macroendocytic processing and entotic cell death by targeting single membranes. Nat Cell Biol 13: 1335-1343.

Fontana L, Partridge L, Longo VD. 2010. Extending healthy life span--from yeast to humans. Science 328: $321-326$.

Galliot B. 2012. Hydra, a fruitful model system for 270 years. Int J Dev Biol 56: 411-423.

Garcia-Prat L, Martinez-Vicente M, Perdiguero E, Ortet L, Rodriguez-Ubreva J, Rebollo E, Ruiz-Bonilla V, Gutarra S, Ballestar E, Serrano AL et al. 2016. Autophagy maintains stemness by preventing senescence. Nature 529: $37-42$.

Gellner K, Praetzel G, Bosch TC. 1992. Cloning and expression of a heat-inducible hsp70 gene in two species of Hydra which differ in their stress response. Eur J Biochem 210: 683-691.

Gomez-Puerto MC, Folkerts H, Wierenga AT, Schepers K, Schuringa JJ, Coffer PJ, Vellenga E. 2016. Autophagy Proteins ATG5 and ATG7 Are Essential for the Maintenance of Human CD34(+) Hematopoietic StemProgenitor Cells. Stem Cells 34: 1651-1663.

Hosokawa N, Hara T, Kaizuka T, Kishi C, Takamura A, Miura Y, lemura S, Natsume T, Takehana K, Yamada N et al. 2009. Nutrient-dependent mTORC1 association with the ULK1-Atg13-FIP200 complex required for autophagy. Mol Biol Cell 20: 1981-1991.

Johansen T, Lamark T. 2011. Selective autophagy mediated by autophagic adapter proteins. Autophagy 7: $279-296$.

Jones KT, Greer ER, Pearce D, Ashrafi K. 2009. Rictor/TORC2 regulates Caenorhabditis elegans fat storage, body size, and development through sgk-1. PLoS Biol 7: e60.

Kaushik S, Cuervo AM. 2015. Proteostasis and aging. Nat Med 21: 1406-1415.

Krajcovic M, Krishna S, Akkari L, Joyce JA, Overholtzer M. 2013. mTOR regulates phagosome and entotic vacuole fission. Mol Biol Cell 24: 3736-3745.

Lan D, Wang W, Zhuang J, Zhao Z. 2015. Proteasome inhibitor-induced autophagy in PC12 cells overexpressing A53T mutant alpha-synuclein. Mol Med Rep 11: 1655-1660.

Littlefield CL, Finkemeier C, Bode HR. 1991. Spermatogenesis in Hydra-Oligactis .2. How Temperature Controls the Reciprocity of Sexual and Asexual Reproduction. Dev Biol 146: 292-300.

Longo VD, Finch CE. 2003. Evolutionary medicine: from dwarf model systems to healthy centenarians? Science 299: 1342-1346.

Madeira JB, Masuda CA, Maya-Monteiro CM, Matos GS, Montero-Lomeli M, Bozaquel-Morais BL. 2015. TORC1 inhibition induces lipid droplet replenishment in yeast. Mol Cell Biol 35: 737-746.

Marcum BA, Campbell RD. 1978. Development of Hydra lacking nerve and interstitial cells. J Cell Sci 29: 17-33.

Martinez DE. 1998. Mortality patterns suggest lack of senescence in hydra. Exp Gerontol 33: 217-225.

Morimoto RI, Cuervo AM. 2009. Protein homeostasis and aging: taking care of proteins from the cradle to the grave. J Gerontol A Biol Sci Med Sci 64: 167-170.

Otto JJ, Campbell RD. 1977. Tissue economics of hydra: regulation of cell cycle, animal size and development by controlled feeding rates. J Cell Sci 28: 117-132.

Pandey UB, Nie Z, Batlevi Y, McCray BA, Ritson GP, Nedelsky NB, Schwartz SL, DiProspero NA, Knight MA, Schuldiner $O$ et al. 2007. HDAC6 rescues neurodegeneration and provides an essential link between autophagy and the UPS. Nature 447: 859-863.

Pankiv S, Clausen TH, Lamark T, Brech A, Bruun JA, Outzen H, Overvatn A, Bjorkoy G, Johansen T. 2007. p62/SQSTM1 binds directly to Atg8/LC3 to facilitate degradation of ubiquitinated protein aggregates by autophagy. J Biol Chem 282: 24131-24145.

Rubinsztein DC. 2007. Autophagy induction rescues toxicity mediated by proteasome inhibition. Neuron 54: 854-856. 
bioRxiv preprint doi: https://doi.org/10.1101/236638; this version posted December 23, 2017. The copyright holder for this preprint (which was not certified by peer review) is the author/funder, who has granted bioRxiv a license to display the preprint in perpetuity. It is made available under aCC-BY-NC-ND 4.0 International license.

Tomczyk et al.

Deficient autophagy and aging in Hydra

Russell RC, Tian Y, Yuan H, Park HW, Chang YY, Kim J, Kim H, Neufeld TP, Dillin A, Guan KL. 2013. ULK1 induces autophagy by phosphorylating Beclin-1 and activating VPS34 lipid kinase. Nat Cell Biol 15: 741-750.

Sanjuan MA, Dillon CP, Tait SW, Moshiach S, Dorsey F, Connell S, Komatsu M, Tanaka K, Cleveland JL, Withoff S et al. 2007. Toll-like receptor signalling in macrophages links the autophagy pathway to phagocytosis. Nature 450: 1253-1257.

Sarbassov DD, Ali SM, Sengupta S, Sheen JH, Hsu PP, Bagley AF, Markhard AL, Sabatini DM. 2006. Prolonged rapamycin treatment inhibits mTORC2 assembly and Akt/PKB. Mol Cell 22: 159-168.

Schaible R, Scheuerlein A, Danko MJ, Gampe J, Martinez DE, Vaupel JW. 2015. Constant mortality and fertility over age in Hydra. Proc Natl Acad Sci U S A 112: 15701-15706.

Schenkelaars Q, Tomczyk S, Wenger Y, Ekundayo K, Girard V, Buzgariu W, Austad S, Galliot B. 2017. Hydra, a model system for deciphering the mechanisms of aging and resistance to aging. In Handbook For Models On Human Aging, (ed. PM Conn). Elsevier.

Schenkelaars Q, Tomczyk S, Wenger Y, Ekundayo K, Girard V, Buzgariu W, Austad S, Galliot B. 2018. Hydra, a model system for deciphering the mechanisms of aging and resistance to aging. In Conn's Handbook For Models On Human Aging, Vol in press (ed. PM Conn, JL Ram). Elsevier.

Shen HM, Mizushima N. 2014. At the end of the autophagic road: an emerging understanding of lysosomal functions in autophagy. Trends Biochem Sci 39: 61-71.

Sugiyama T, Fujisawa T. 1978. Genetic analysis of developmental mechanisms in Hydra. II. Isolation and characterization of an interstitial cell-deficient strain. J Cell Sci 29: 35-52.

Thiam AR, Farese RV, Jr., Walther TC. 2013. The biophysics and cell biology of lipid droplets. Nat Rev Mol Cell Biol 14: 775-786.

Warr MR, Binnewies M, Flach J, Reynaud D, Garg T, Malhotra R, Debnath J, Passegue E. 2013. FOXO3A directs a protective autophagy program in haematopoietic stem cells. Nature 494: 323-327.

Wenger Y, Buzgariu W, Galliot B. 2016. Loss of neurogenesis in Hydra leads to compensatory regulation of neurogenic and neurotransmission genes in epithelial cells. Philos Trans B 371: 20150040.

Wenger Y, Galliot B. 2013. Punctuated emergences of genetic and phenotypic innovations in eumetazoan, bilaterian, euteleostome, and hominidae ancestors. Genome Biol Evol 5: 1949-1968.

Wullschleger S, Loewith R, Hall MN. 2006. TOR signaling in growth and metabolism. Cell 124: 471-484.

Yla-Anttila P, Mikkonen E, Happonen KE, Holland P, Ueno T, Simonsen A, Eskelinen EL. 2015. RAB24 facilitates clearance of autophagic compartments during basal conditions. Autophagy 11: 1833-1848.

Yoshida K, Fujisawa T, Hwang JS, Ikeo K, Gojobori T. 2006. Degeneration after sexual differentiation in hydra and its relevance to the evolution of aging. Gene 385: 64-70. 